Supporting Information for

\title{
An Application Exploiting Aurophilic Bonding and iClick to Produce White Light Emitting Materials.
}

Christopher C. Beto, ${ }^{\mathrm{a}}$ Charles J. Zeman IV, ${ }^{\mathrm{a}}$ Yajing Yang, ${ }^{\mathrm{b}}$ James. D. Bullock, ${ }^{\mathrm{a}}$ Ethan D. Holt, ${ }^{\mathrm{a}}$ Alexander Q. Kane, ${ }^{\mathrm{a}}$ Trevor A. Makal, ${ }^{\mathrm{a}}$ Xi Yang, ${ }^{\mathrm{a}}$ Ion Ghiviriga, ${ }^{\mathrm{a}}$ Kirk S. Schanze, ${ }^{\mathrm{b} *}$ and Adam S. Veige ${ }^{\mathrm{a} *}$

aUniversity of Florida, Department of Chemistry, Center for Catalysis, P.O. Box 117200, Gainesville, FL, 32611.

${ }^{b}$ University of Texas at San Antionio, Department of Chemistry, One UTSA Circle, San Antonio, TX 78249

\section{Contents}

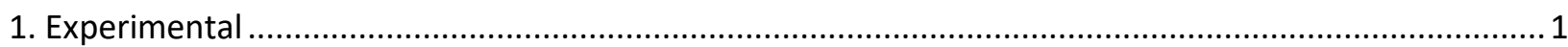

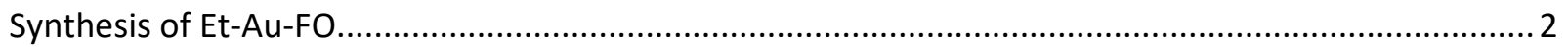

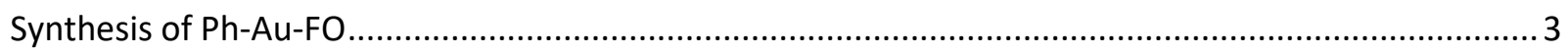

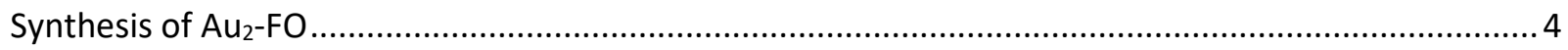

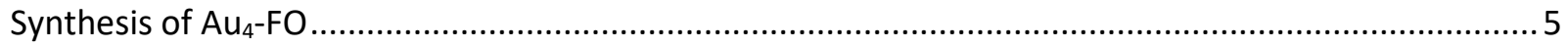

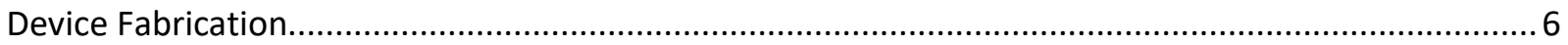

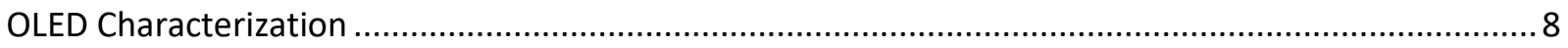

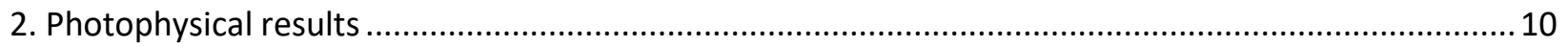

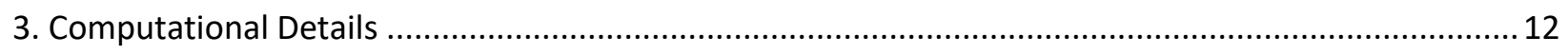

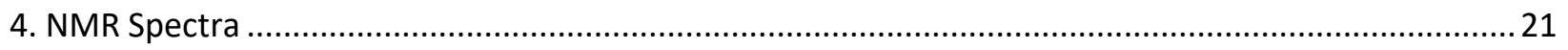

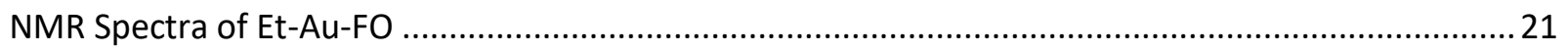

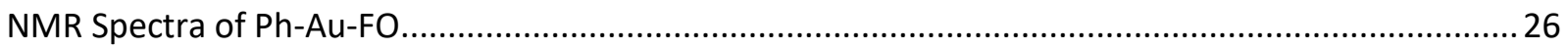

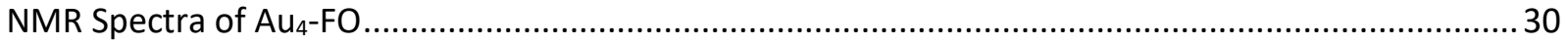

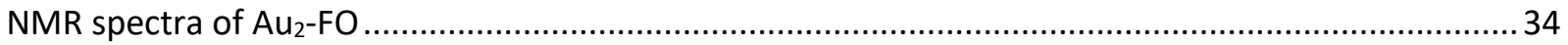

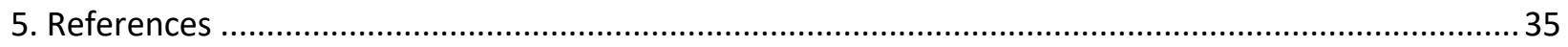




\section{Warning!}

Metal-azides are known to be contact explosives.

\section{Experimental}

\section{Synthesis of Et-Au-FO}

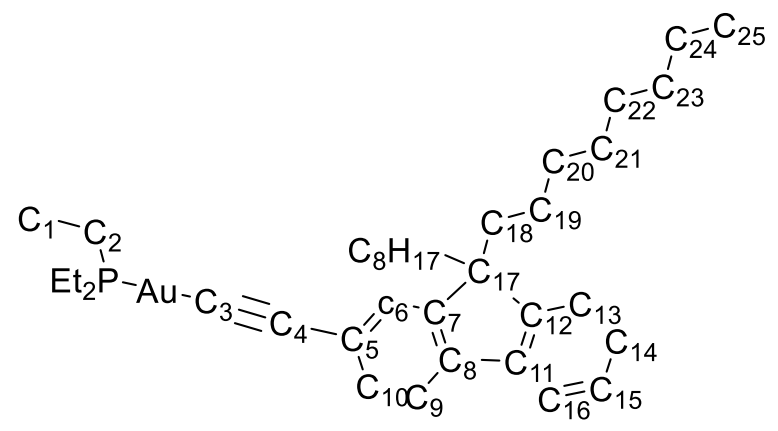

A THF/MeOH (1:1, $10 \mathrm{ml})$ solution of $\mathrm{PEt}_{3} \mathrm{AuCl}$ (149.7 mg, $\left.0.427 \mathrm{mmol}\right)$, ((9,9-dioctyl-9Hfluoren-2-yl)ethynyl)trimethylsilane (213.6 mg, $0.439 \mathrm{mmol}, 1.03 \mathrm{equiv})$, and $\mathrm{NaOH}$ (95.0 mg, $2.38 \mathrm{mmol}, 5.4$ equiv) was stirred in the dark at room temperature for $16 \mathrm{~h}$. Solvent was removed in vacuo followed by trituration with dichloromethane three times. The residue was extracted with toluene and filtered through a plug of Celite ${ }^{\circledR}$. The filtrate was evaporated to dryness and the resulting oil was taken up into DCM and passed through a plug of basic alumina. The filtrate was again evaporated in vacuo resulting in a red-gold oil (yield: $259.0 \mathrm{mg}, 83.2 \%) .{ }^{1} \mathrm{H}$ NMR (500 $\left.\mathrm{MHz}, \mathrm{CDCl}_{3}, 25^{\circ} \mathrm{C}, \delta(\mathrm{ppm})\right): 7.63\left(\mathrm{~d},{ }^{3} J_{\mathrm{HH}}=7.1 \mathrm{~Hz}, 1 \mathrm{H}, H \mathrm{C}_{16}\right), 7.56\left(\mathrm{~d},{ }^{3} J_{\mathrm{HH}}=7.7 \mathrm{~Hz}, 1 \mathrm{H}, H \mathrm{C}_{9}\right)$, $7.49\left(\mathrm{~s}, 1 \mathrm{H}, H \mathrm{C}_{6}\right), 7.46\left(\mathrm{dd},{ }^{3} J_{\mathrm{HH}}=7.7 \mathrm{~Hz},{ }^{4} J_{\mathrm{HH}}=-1.1 \mathrm{~Hz}, 1 \mathrm{H}, H \mathrm{C}_{10}\right), 7.29\left(\mathrm{~m}, 1 \mathrm{H}, H \mathrm{C}_{13}\right), 7.27$ $\left(\mathrm{m}, 1 \mathrm{H}, H \mathrm{C}_{15}\right), 7.25\left(\mathrm{~m}, 1 \mathrm{H}, H \mathrm{C}_{14}\right), 1.90\left(\mathrm{t},{ }^{3} J_{\mathrm{HH}}=8.2 \mathrm{~Hz}, 4 \mathrm{H}, H \mathrm{C}_{18}\right), 1.82\left(\mathrm{dt},{ }^{2} J_{\mathrm{PH}}=-17.6 \mathrm{~Hz}\right.$, $\left.{ }^{3} J_{\mathrm{HH}}=7.7 \mathrm{~Hz}, 6 \mathrm{H}, H \mathrm{C}_{2}\right), 1.22\left(\mathrm{dt},{ }^{2} J_{\mathrm{PH}}=-18.1 \mathrm{~Hz},{ }^{3} J_{\mathrm{HH}}=7.7 \mathrm{~Hz}, 9 \mathrm{H}, H \mathrm{C}_{1}\right), 1.20\left(\mathrm{~m}, 4 \mathrm{H}, H \mathrm{C}_{20}\right)$, $1.11\left(\mathrm{~m}, 4 \mathrm{H}, H \mathrm{C}_{21}\right), 1.07\left(\mathrm{~m}, 4 \mathrm{H}, H \mathrm{C}_{22}\right), 1.00\left(\mathrm{~m}, 8 \mathrm{H}, H \mathrm{C}_{23-24}\right), 0.82\left(\mathrm{t},{ }^{3} J_{\mathrm{HH}}=7.1 \mathrm{~Hz}, 6 \mathrm{H}, H \mathrm{C}_{25}\right)$, $0.56\left(\mathrm{~m}, 4 \mathrm{H}, H \mathrm{C}_{19}\right) .{ }^{13} \mathrm{C}\left\{{ }^{1} \mathrm{H}\right\} \mathrm{NMR}\left(125 \mathrm{MHz}, \mathrm{CDCl} 3,25{ }^{\circ} \mathrm{C}, \delta(\mathrm{ppm})\right): 150.9\left(\mathrm{C}_{12}\right), 150.2\left(\mathrm{C}_{7}\right)$, $140.8\left(\mathrm{C}_{11}\right), 139.8\left(\mathrm{C}_{8}\right), 130.9\left(\mathrm{C}_{10}\right), 127.1\left(\mathrm{C}_{6}\right), 126.8\left(\mathrm{C}_{14}\right), 126.6\left(\mathrm{C}_{15}\right), 123.1\left(\mathrm{C}_{5}\right), 122.7\left(\mathrm{C}_{13}\right)$, 119.6 ( $\left.\mathrm{C}_{16}\right), 119.2\left(\mathrm{C}_{9}\right), 105.2\left(\mathrm{C}_{4}\right), 54.9\left(\mathrm{C}_{17}\right), 40.5\left(\mathrm{C}_{18}\right), 31.7\left(\mathrm{C}_{21}\right), 30.1\left(\mathrm{C}_{23}\right), 29.3\left(\mathrm{C}_{22,24}\right), 23.7$ 
$\left(\mathrm{C}_{19}\right), 22.6\left(\mathrm{C}_{20}\right), 1.82\left(\mathrm{C}_{2}\right), 14.1\left(\mathrm{C}_{25}\right), 8.9\left(\mathrm{C}_{1}\right) .{ }^{31} \mathrm{P}\left\{{ }^{1} \mathrm{H}\right\}$ NMR $\left(121.4 \mathrm{MHz}, \mathrm{CDCl}_{3}, 25{ }^{\circ} \mathrm{C}, \delta\right.$ (ppm)): 38.1 (s). Anal. Calcd. (\%) for $\mathrm{C}_{37} \mathrm{H}_{56} \mathrm{AuP}$ : C, 60.98; H, 7.75. Found: C, 61.97; H, 7.96. HRMS (ESI): $\mathrm{m} / \mathrm{z}$ calcd. for $\mathrm{C}_{37} \mathrm{H}_{56} \mathrm{AuP},[\mathrm{M}+\mathrm{H}]^{+}:$729.3858; found: 729.3866 ; $[\mathrm{M}+\mathrm{Na}]^{+}$: 751.3677; found: 751.3691 .

\section{Synthesis of Ph-Au-FO}

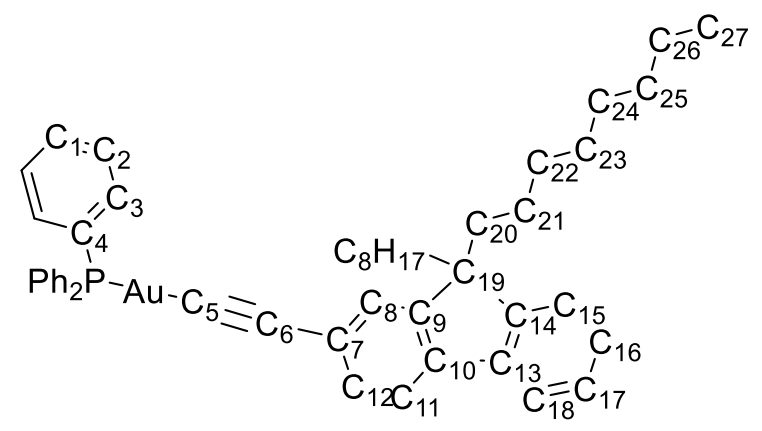

A THF/MeOH $(1: 1,10 \mathrm{ml})$ solution of $\mathrm{PPh}_{3} \mathrm{AuCl}(144.1 \mathrm{mg}, 0.291 \mathrm{mmol})$, ((9,9-dioctyl-9Hfluoren-2-yl)ethynyl)trimethylsilane ( $155.4 \mathrm{mg}, 0.319 \mathrm{mmol}, 1.1$ equiv), and $\mathrm{NaOH}$ (60.9 mg, 1.52 mmol, 4.8 equiv) was stirred in the dark at room temperature for $16 \mathrm{~h}$. Solvent was removed in vacuo followed by trituration with dichloromethane three times. The residue was extracted with toluene and filtered through a plug of Celite ${ }^{\circledR}$. The filtrate was concentrated and layered with pentane to precipitate the product. The supernatant was removed by decanting resulting in a lightyellow powder (yield: $\left.83.6 \mathrm{mg}, 32.9 \% \mathrm{PPh}_{3} \mathrm{AuCl}\right) .{ }^{1} \mathrm{H} \mathrm{NMR}\left(500 \mathrm{MHz}, \mathrm{CDCl}_{3}, 25{ }^{\circ} \mathrm{C}, \delta(\mathrm{ppm})\right.$ ): $7.64\left(\mathrm{~d},{ }^{3} J_{\mathrm{HH}}=7.1 \mathrm{~Hz}, 1 \mathrm{H}, H \mathrm{C}_{18}\right) 7.58\left(\mathrm{~m}, 7 \mathrm{H}, H \mathrm{C}_{3,11}\right), 7.52\left(\mathrm{~m}, 1 \mathrm{H}, H \mathrm{C}_{12}\right) .7 .51\left(\mathrm{~m}, 3 \mathrm{H}, H_{1}\right)$, $7.50\left(\mathrm{~m}, 1 \mathrm{H}, H \mathrm{C}_{8}\right), 7.47\left(\mathrm{~m}, 6 \mathrm{H}, H \mathrm{C}_{2}\right), 7.31\left(\mathrm{~m}, 1 \mathrm{H}, H \mathrm{C}_{15}\right), 7.29\left(\mathrm{~m}, 1 \mathrm{H}, H \mathrm{C}_{17}\right), 7.26(\mathrm{~m}, 1 \mathrm{H}$, $\left.H \mathrm{C}_{16}\right), 1.92\left(\mathrm{t},{ }^{3} J_{\mathrm{HH}}=8.2 \mathrm{~Hz}, 4 \mathrm{H}, H \mathrm{C}_{20}\right), 1.20\left(\right.$ quin, $\left.{ }^{3} J_{\mathrm{HH}}=7.1 \mathrm{~Hz}, 4 \mathrm{H}, H \mathrm{C}_{22}\right), 1.11\left(\mathrm{~m}, 4 \mathrm{H}, H \mathrm{C}_{23}\right)$, $1.07\left(\mathrm{~m}, 4 \mathrm{H}, H \mathrm{C}_{24}\right), 1.01\left(\mathrm{~m}, 8 \mathrm{H}, H \mathrm{C}_{24-25}\right), 0.81\left(\mathrm{t},{ }^{3} J_{\mathrm{HH}}=7.1 \mathrm{~Hz}, 6 \mathrm{H}, H \mathrm{C}_{26}\right), 0.56\left(\mathrm{~m}, 4 \mathrm{H}, H \mathrm{C}_{21}\right)$. ${ }^{13} \mathrm{C}\left\{{ }^{1} \mathrm{H}\right\}$ NMR $\left(125 \mathrm{MHz}, \mathrm{CDCl} 3,25{ }^{\circ} \mathrm{C}, \delta(\mathrm{ppm})\right): 151.0\left(\mathrm{C}_{14}\right), 150.2\left(\mathrm{C}_{9}\right), 140.8\left(\mathrm{C}_{13}\right), 140.0$ $\left(\mathrm{C}_{10}\right), 134.3\left(\mathrm{C}_{3}\right), 131.6\left(\mathrm{C}_{1}\right), 131.0\left(\mathrm{C}_{8}\right), 129.5\left(\mathrm{C}_{4}\right), 129.1\left(\mathrm{C}_{2}\right), 127.1\left(\mathrm{C}_{12}\right), 126.9\left(\mathrm{C}_{16}\right), 126.6$ $\left(\mathrm{C}_{17}\right), 122.9\left(\mathrm{C}_{7}\right), 122.7\left(\mathrm{C}_{15}\right), 119.6\left(\mathrm{C}_{18}\right), 119.2\left(\mathrm{C}_{11}\right), 105.4\left(\mathrm{C}_{6}\right), 54.9\left(\mathrm{C}_{19}\right), 40.5\left(\mathrm{C}_{20}\right), 31.8$ 
$\left(\mathrm{C}_{23}\right), 30.1\left(\mathrm{C}_{25}\right), 29.3\left(\mathrm{C}_{24,26}\right), 22.6\left(\mathrm{C}_{22}\right), 23.7\left(\mathrm{C}_{21}\right), 14.1\left(\mathrm{C}_{27}\right) .{ }^{31} \mathrm{P}\left\{{ }^{1} \mathrm{H}\right\}$ NMR $(121.4 \mathrm{MHz}$, $\left.\mathrm{CDCl}_{3}, 25{ }^{\circ} \mathrm{C}, \delta(\mathrm{ppm})\right): 42.4$ (s). Anal. Calcd. (\%) for $\mathrm{C}_{49} \mathrm{H}_{56} \mathrm{AuP}: \mathrm{C}, 67.42 ; \mathrm{H}, 6.47$. Found: $\mathrm{C}$, 67.80; H, 6.20. HRMS (ESI): $m / z$ calcd. for $\mathrm{C}_{49} \mathrm{H}_{56} \mathrm{AuP},[\mathrm{M}+\mathrm{H}]^{+}$: 873.3858; found: 873.3858; $[\mathrm{M}+\mathrm{Na}]^{+}:$895.3677; found: 895.3681.

\section{Synthesis of $\mathrm{Au}_{2}-\mathrm{FO}$}

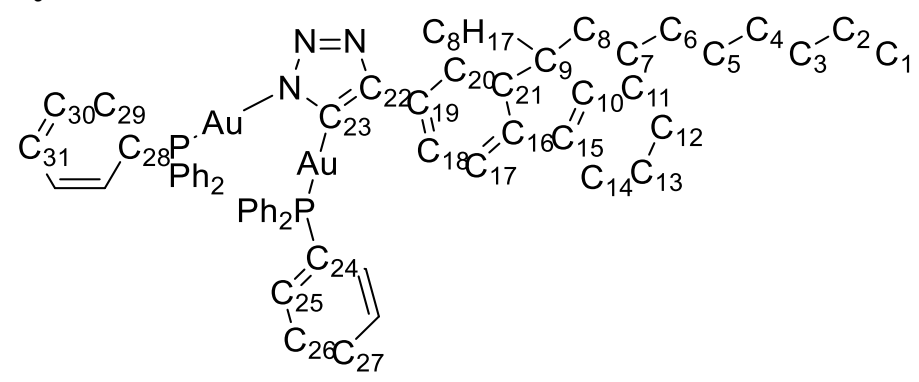

A $5 \mathrm{ml}$ solution of Ph-Au-OF (0.119 mg, $0.136 \mathrm{mmol})$ and $\mathrm{PPh}_{3} \mathrm{AuN}_{3}(0.068 \mathrm{mg}, 0.136$ $\mathrm{mmol})$ in benzene $(5 \mathrm{~mL})$ was stirred at room temperature while kept dark for $3 \mathrm{~d}$. The solution was concentrated and then hexanes was added to precipitate the product. The precipitate was then dissolved in toluene and cooled to $-30{ }^{\circ} \mathrm{C}$ yielding a white solid that was isolated by decanting the supernatant (yield: $0.044 \mathrm{mg}, 24 \%) .{ }^{1} \mathrm{H} \mathrm{NMR}\left(500 \mathrm{MHz}, \mathrm{CDCl}_{3}, 25^{\circ} \mathrm{C}, \delta(\mathrm{ppm})\right.$ ): $8.61\left(\mathrm{~d},{ }^{3} J_{\mathrm{HH}}=7.6 \mathrm{~Hz}, 1 \mathrm{H}, H \mathrm{C}_{18}\right), 8.39\left(\mathrm{~s}, 1 \mathrm{H}, H \mathrm{C}_{20}\right), 7.66\left(\mathrm{~d},{ }^{3} J_{\mathrm{HH}}=7.1 \mathrm{~Hz}, 1 \mathrm{H}, H \mathrm{C}_{14}\right), 7.56(\mathrm{~d}$, $\left.{ }^{3} J_{\mathrm{HH}}=8.0 \mathrm{~Hz}, 1 \mathrm{H}, H \mathrm{C}_{17}\right), 7.54\left(\mathrm{~m}, 12 \mathrm{H}, H \mathrm{C}_{25}, H \mathrm{C}_{29}\right), 7.43\left(\mathrm{~m}, 6 \mathrm{H}, H \mathrm{C}_{31}, H \mathrm{C}_{27}\right), 7.30(\mathrm{~m}, 2 \mathrm{H}$, $\left.H \mathrm{C}_{13}, H \mathrm{C}_{11}\right), 7.27\left(\mathrm{~m}, 12 \mathrm{H}, H \mathrm{C}_{30}, H \mathrm{C}_{26}\right), 7.24\left(\mathrm{~m}, 1 \mathrm{H}, H \mathrm{C}_{12}\right), 1.92\left(\right.$ dquin, ${ }^{3} J_{\mathrm{HH}}=6.3 \mathrm{~Hz},{ }^{3} J_{\mathrm{HH}}=$ $\left.4.4 \mathrm{~Hz}, 4 \mathrm{H}, H \mathrm{C}_{8}\right), 1.18\left(\mathrm{sept},{ }^{3} \mathrm{JHH}_{\mathrm{HH}}=7.1 \mathrm{~Hz}, 4 \mathrm{H}, H \mathrm{C}_{6}\right), 1.09\left(\mathrm{~m}, 4 \mathrm{H}, H \mathrm{C}_{5}\right), 1.04\left(\mathrm{~m}, 4 \mathrm{H}, H \mathrm{C}_{4}\right)$, $0.98\left(\mathrm{~m}, 4 \mathrm{H}, H \mathrm{C}_{3}\right), 0.97\left(\mathrm{~m}, 4 \mathrm{H}, H \mathrm{C}_{2}\right), 0.81\left(\mathrm{t},{ }^{3} J_{\mathrm{HH}}=7.1 \mathrm{~Hz}, 6 \mathrm{H}, H \mathrm{C}_{1}\right), 0.63\left(\mathrm{dm},{ }^{3} J_{\mathrm{HH}}=75.4\right.$ $\left.\mathrm{Hz}, 4 \mathrm{H}, H \mathrm{C}_{7}\right) .{ }^{13} \mathrm{C}\left\{{ }^{1} \mathrm{H}\right\} \operatorname{NMR}\left(125 \mathrm{MHz}, \mathrm{CDCl} 3,25{ }^{\circ} \mathrm{C}, \delta(\mathrm{ppm})\right): 142.0\left(\mathrm{C}_{15}\right), 142.0\left(\mathrm{C}_{24}, \mathrm{C}_{28}\right)$, $138.5\left(\mathrm{C}_{16}\right), 135.7\left(\mathrm{C}_{19}\right), 134.3\left(\mathrm{C}_{25}, \mathrm{C}_{15}\right), 131.5\left(\mathrm{C}_{27}, \mathrm{C}_{31}\right), 129.2\left(\mathrm{C}_{26}, \mathrm{C}_{30}\right), 126.4\left(\mathrm{C}_{13}\right), 126.0$ $\left(\mathrm{C}_{12}\right), 124.9\left(\mathrm{C}_{22}\right), 124.8\left(\mathrm{C}_{18}\right), 122.8\left(\mathrm{C}_{11}\right), 120.8\left(\mathrm{C}_{20}\right), 119.0\left(\mathrm{C}_{15}, \mathrm{C}_{15}\right) .{ }^{31} \mathrm{P}\left\{{ }^{1} \mathrm{H}\right\}$ NMR $(121.4$ 
$\left.\mathrm{MHz}, \mathrm{CDCl}_{3}, 25^{\circ} \mathrm{C}, \delta(\mathrm{ppm})\right): 44.3$ (P-Au-C) and $32.2(\mathrm{P}-\mathrm{Au}-\mathrm{N})$. HRMS (ESI): $\mathrm{m} / z$ calcd. for $\mathrm{C}_{67} \mathrm{H}_{72} \mathrm{Au}_{2} \mathrm{~N}_{3} \mathrm{P}_{2},[\mathrm{M}+\mathrm{H}]^{+}:$1374.4527; found: 1374.4517.

\section{Synthesis of Au4-FO}

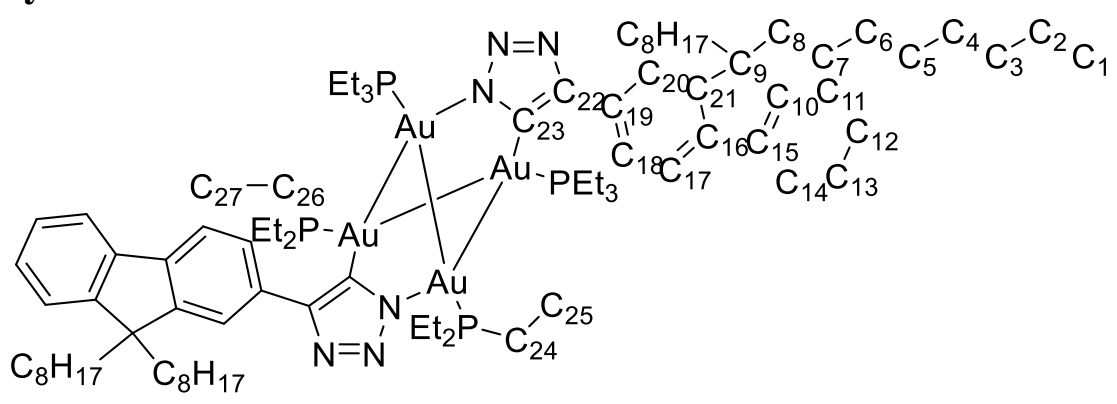

A $5 \mathrm{ml}$ solution of Et-Au-OF (66.3 mg, $0.091 \mathrm{mmol})$ and $\mathrm{PEt}_{3} \mathrm{AuN}_{3}(35.7 \mathrm{mg}, 0.100 \mathrm{mmol})$ in dichloromethane was stirred in the dark at room temperature for $5 \mathrm{~d}$. The solution was concentrated and hexanes was added to precipitate excess $\mathrm{PEt}_{3} \mathrm{AuN}_{3}$. The product was isolated by filtration to yield a golden oil (yield: $74.7 \mathrm{mg}, 75.6 \%) .{ }^{1} \mathrm{H}$ NMR $\left(500 \mathrm{MHz}, \mathrm{CDCl}_{3}, 25{ }^{\circ} \mathrm{C}, \delta(\mathrm{ppm})\right): 8.69(\mathrm{dd}$, $\left.{ }^{3} J_{\mathrm{HH}}=8.2 \mathrm{~Hz},{ }^{4} J_{\mathrm{HH}}=-1.1 \mathrm{~Hz}, 2 \mathrm{H} H \mathrm{C}_{18}\right), 8.24\left(\mathrm{~s}, 2 \mathrm{H}, H \mathrm{C}_{20}\right), 7.53\left(\mathrm{~m}, 2 \mathrm{H}, H \mathrm{C}_{17}\right), 7.64(\mathrm{~m}, 2 \mathrm{H}$, $\left.H \mathrm{C}_{14}\right), 7.31\left(\mathrm{~m}, 2 \mathrm{H}, H \mathrm{C}_{11}\right), 7.28\left(\mathrm{~m}, 2 \mathrm{H}, H \mathrm{C}_{13}\right), 7.24\left(\mathrm{~m}, 2 \mathrm{H}, H \mathrm{C}_{12}\right), 2.01\left(\mathrm{~m}, 8 \mathrm{H}, H \mathrm{C}_{8}\right), 1.84,1.52$ $\left(\mathrm{m}, 24 \mathrm{H}, H_{24}, 26\right), 1.23\left(\mathrm{~m}, 18 \mathrm{H}, H \mathrm{C}_{25}\right), 1.19\left(\mathrm{~m}, 8 \mathrm{H}, H \mathrm{C}_{2}\right), 1.11\left(\mathrm{~m}, 8 \mathrm{H}, H_{3}\right), 1.10(\mathrm{~m}, 18 \mathrm{H}$, $\left.H \mathrm{C}_{27}\right), 1.08\left(\mathrm{~m}, 8 \mathrm{H}, H \mathrm{C}_{6}\right), 1.02\left(\mathrm{~m}, 16 \mathrm{H}, H \mathrm{C}_{4-5}\right), 0.82\left(\mathrm{~m}, 12 \mathrm{H}, H \mathrm{C}_{1}\right), 0.70\left(\mathrm{~m}, 4 \mathrm{H}, H \mathrm{C}_{7}\right), 0.59(\mathrm{~m}$, $\left.4 \mathrm{H}, H \mathrm{C}_{7}\right) .{ }^{13} \mathrm{C}\left\{{ }^{1} \mathrm{H}\right\}$ NMR $\left(125 \mathrm{MHz}, \mathrm{CDCl} 3,25{ }^{\circ} \mathrm{C}, \delta(\mathrm{ppm})\right): 150.9\left(\mathrm{C}_{10}\right), 150.8\left(\mathrm{C}_{21}\right), 141.6$ $\left(\mathrm{C}_{15}\right), 138.3\left(\mathrm{C}_{16}\right), 136.4\left(\mathrm{C}_{19}\right), 126.5\left(\mathrm{C}_{13}\right), 126.1\left(\mathrm{C}_{12}\right), 125.3\left(\mathrm{C}_{18}\right), 122.8\left(\mathrm{C}_{11}\right), 121.0\left(\mathrm{C}_{20}\right), 118.9$ $\left(\mathrm{C}_{14}\right), 118.3\left(\mathrm{C}_{17}\right), 54.8\left(\mathrm{C}_{9}\right), 40.7\left(\mathrm{C}_{8}\right), 31.7\left(\mathrm{C}_{3}\right), 30.2\left(\mathrm{C}_{4-5}\right), 29.4\left(\mathrm{C}_{6}\right), 23.8\left(\mathrm{C}_{7}\right), 22.7\left(\mathrm{C}_{2}\right), 18.4$ $\left(\mathrm{C}_{24,26}\right), 17.1\left(\mathrm{C}_{24,26}\right), 14.0\left(\mathrm{C}_{1}\right), 9.0\left(\mathrm{C}_{25,27}\right), 8.5\left(\mathrm{C}_{25,27}\right) .{ }^{31} \mathrm{P}\left\{{ }^{1} \mathrm{H}\right\}$ NMR (121.4 MHz, $\mathrm{CDCl}_{3}, 25$ $\left.{ }^{\circ} \mathrm{C}, \delta(\mathrm{ppm})\right): 31.3\left(\mathrm{~s}, P_{26}\right), 20.2\left(\mathrm{~s}, P \mathrm{C}_{24}\right)$. Anal. Calcd. (\%) for $\mathrm{C}_{86} \mathrm{H}_{142} \mathrm{Au}_{2} \mathrm{P}_{4} \mathrm{~N}_{6}: \mathrm{C}, 47.56 ; \mathrm{H}$, 6.59; N, 3.87. Found: C, 47.14; H, 6.50; N, 3.26. 


\section{Device Fabrication}

Pre-patterned indium tin oxide (ITO) coated glass substrates were purchased from Kintec with a sheet resistance of $20 \mathrm{ohm} / \mathrm{sq}$. The ITO substrate was cleaned by scrubbing the surface with a sodium dodecylsulfate (SDS) solution soaked Kimwipe followed by; sonication in SDS solution, deionized water, deionized water (18 M $)$, acetone, and isopropanol for $15 \mathrm{~min}$ each. After sonication the substrates were removed from the isopropanol solution and blown dry with nitrogen and transferred into the plasma cleaner inside a particle free hood. The substrates were then exposed to an oxygen plasma for 20 minutes following 3 oxygen purge cycles ( $5 \mathrm{sec}$ each).

Immediately following oxygen plasma cleaning, the substrates were spun cast with PEDOT:PSS at $3000 \mathrm{RPM}$ for $45 \mathrm{~s}$ with a $3 \mathrm{~s}$ initial ramp. The PEDOT:PSS solution was filtered with a 0.45 $\mu \mathrm{m}$ nylon syringe directly to the substrate for spin coating. Plasma cleaning and spin coating of the PEDOT:PSS layer were performed in a custom build particle free hood with $0.3 \mu \mathrm{m}$ Hepa filter. The contact corners were then wiped with water to remove the PEDOT:PSS layer. The substrates were then placed on a hotplate at $130{ }^{\circ} \mathrm{C}$ for annealing for $15 \mathrm{~min}$, then transferred to an aluminum block to cool. After annealing the PEDOT:PSS coated substrates were placed into individual plastic containers which were then placed in a larger plastic container equipped with $0.45 \mu \mathrm{m}$ nylon filters to reduce particle exposure and then transferred to an argon atmosphere glovebox.

PVK, PBD, and $\mathrm{Au}_{4}-\mathrm{FO}$ were weighed in separate vials before bringing them into the glove box. Solutions of PVK and PBD were made with concentrations of $20 \mathrm{mg} / \mathrm{mL}$ in chlorobenzene while the solution of Au4-FO was made with a concentration of $8 \mathrm{mg} / \mathrm{mL}$ in chlorobenzene. All solutions were then allowed to stir for at least $24 \mathrm{~h}$ before spin coating. Solutions of PVK, PBD, and Au4-FO were made by combining the solutions to form a mixture with the desired ratio of host to emitter providing precise control of the host to emitter ratio. Spin coating of the emissive 
layer containing PVK, PBD, and Au4-FO was done at 1000 RPM for 1 min followed by thermal annealing at $80^{\circ} \mathrm{C}$. Once annealing was complete the contacts were wiped with chloroform to remove the emissive layer and expose the ITO. After annealing the devices were transferred to the thermal evaporator where the chamber was pumped down to $\sim 1 \times 10^{-6}$ mbar and remained under vacuum for 8-12 h. The cathode of the OLEDs consisted of two additional layers (1 nm LiF and $100 \mathrm{~nm} \mathrm{Al})$. After evaporation the devices were stored in the glovebox until testing.

To investigate whether Au4-FO was compatible with the host materials OXD-7, with a higher triplet energy of $2.7 \mathrm{eV}$, was employed as an electron transport material. For these devices the fabrication procedure was the same as above but with a ratio of PVK:OXD-7 of 2:1 by weight. The device structure and performance are shown in Figure S1 and Figure S2, respectively. Note the lack of emission maxima at $450 \mathrm{~nm}$.

\begin{tabular}{|c|}
\hline Al \\
\hline LiF \\
\hline PVK:OXD-74\% $\mathrm{Au}_{4}$-FO \\
\hline PEDOT:PSS \\
\hline ITO \\
\hline
\end{tabular}
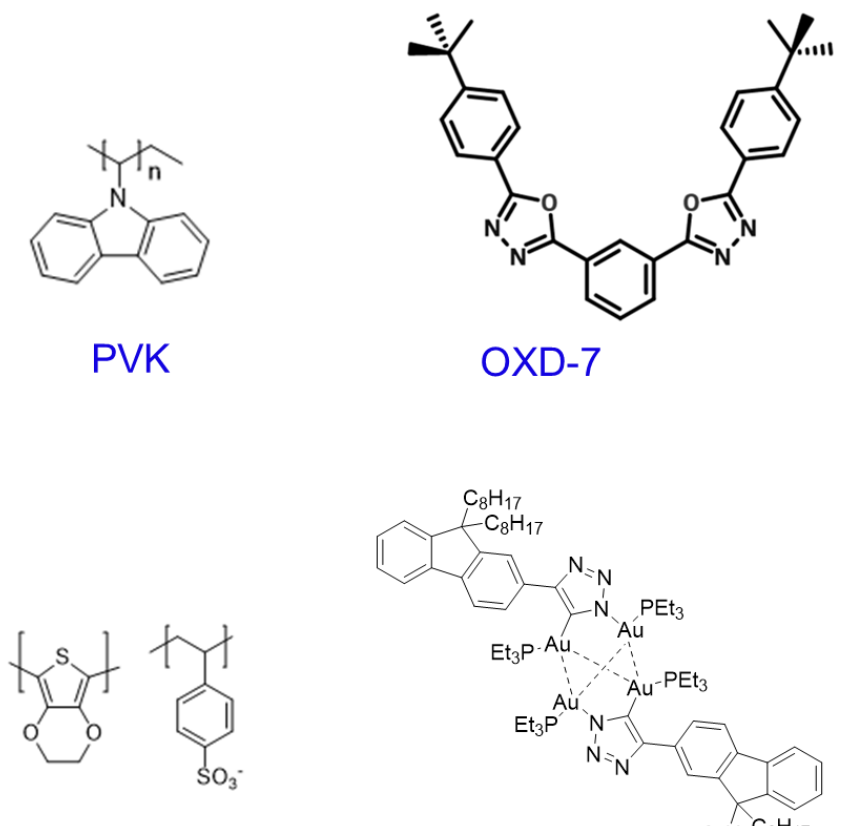

PEDOT:PSS

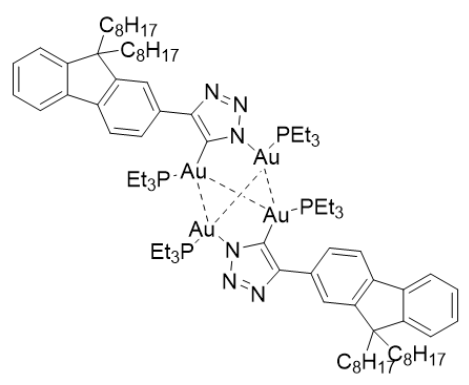

$\mathrm{Au}_{4}-\mathrm{FO}$

Figure S1. Device structure with materials used. 

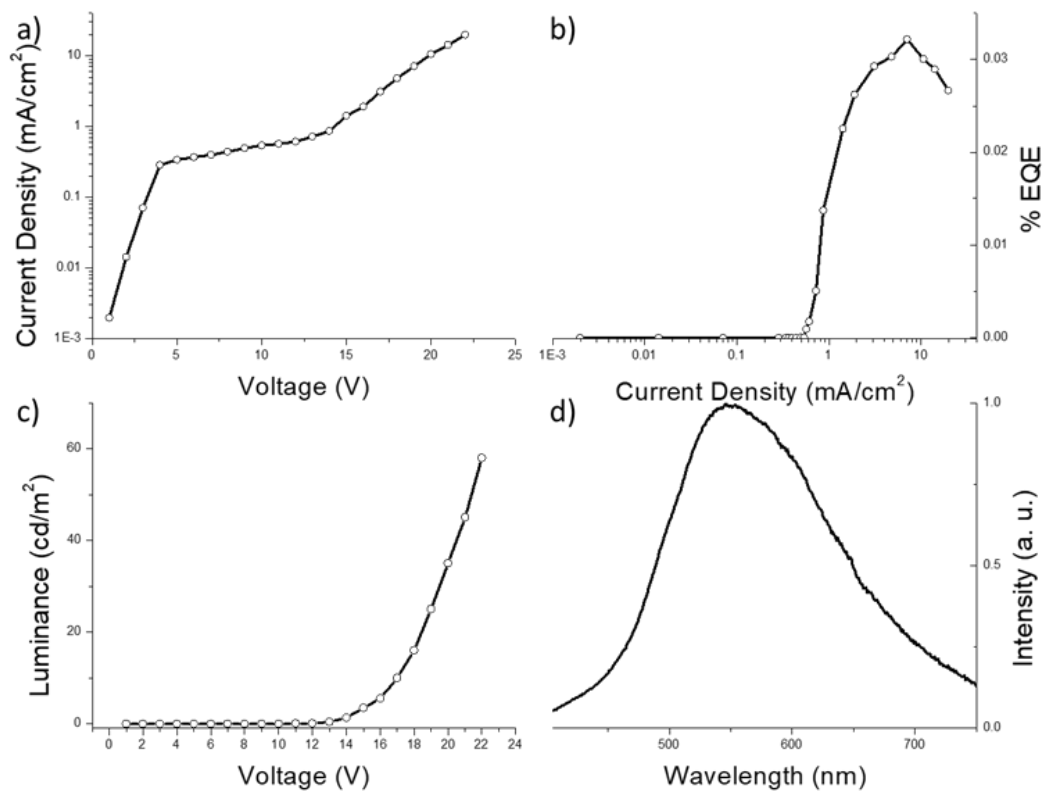

Figure S2. Au4-FO device performance with OXD-7. a) Current-Density Voltage Characteristics. b) EQE current-density characteristics. c) Luminance voltage characteristics. d) Electroluminescence at $16 \mathrm{~V}$

\section{OLED Characterization}

The devices were characterized by supplying a voltage bias and measuring the current with a Keithley 2400 sourcemeter. The optical power was measured using a UDT instruments silicon photodiode and optometer. The photodiode was incorporated into a custom-built holder for the photodiode and then a separate o-ring sealed device holder with spring loaded contacts held the OLED device. The details of the set up along with calibration were reported previously. ${ }^{1}$ Electroluminescent spectra were recorded using an Spex Fluorolog 2 with constant voltage applied to the device by a Keithley 2400 sourcemeter.

The percent External Quantum Efficiency (\%EQE) is defined as the ratio of the number of photons emitted in the forward direction relative to the number of electrons injected. The number of photons emitted is calculated by equation 1 and the number of electrons is calculated by equation 
2. From the definition of $\% \mathrm{EQE}$ Equations 1 and 2 can be combined to arrive at equation 3 . The luminance for the monochromatic emitter is determined by equation 4 calculated in $\mathrm{cd} / \mathrm{m}^{2}$.

$$
\begin{gathered}
\text { Photons } / \text { area }=\frac{I_{\text {det }} \lambda}{f h c R} \\
\text { Electrons } / \text { area }=\frac{I_{O L E D}}{e A} \\
\% \text { EQE }=100 \times \frac{I_{\text {det }} \lambda e}{h c f I_{O L E D} R} \\
\text { Photopic Response }=\frac{683 g I_{\text {det }}}{f R A \pi}
\end{gathered}
$$

Where $I_{\text {det }}$ is the photocurrent measured by the photodiode, $\lambda$ is the wavelength of peak intensity, $f$ is the fraction of light collected, $\mathrm{h}$ is Plank's constant $6.626 \times 10^{-34} \mathrm{~J} \bullet \mathrm{s}, \mathrm{c}$ is the speed of light $2.99 \times 10^{8} \mathrm{~m} / \mathrm{s}, \mathrm{R}$ is the photodiode response at $\lambda$ max, $\mathrm{A}$ is the device area $0.0707 \mathrm{~cm}^{2}$, IOLED is the OLED current, e is the electronic charge $1.6 \times 10-19 \mathrm{C}$, and $\mathrm{g}$ is the photopic response of the human eye at $\lambda$ max.

Equations 1 through 4 assume the emitter is monochromatic. If the monochromatic assumption is removed equation 3 becomes equation 5 and equation 4 becomes equation $6 .^{2}$

$$
\begin{gathered}
\% E Q E=100 \times \frac{e \int \lambda I_{\text {det }}(\lambda) d \lambda}{h c f I_{\text {OLED }} \int R(\lambda) d \lambda} \\
\text { Photopic Response }=\frac{683 \int g(\lambda) I_{d e t}(\lambda) d \lambda}{f A \pi \int R(\lambda) d \lambda}
\end{gathered}
$$




\section{Photophysical results}

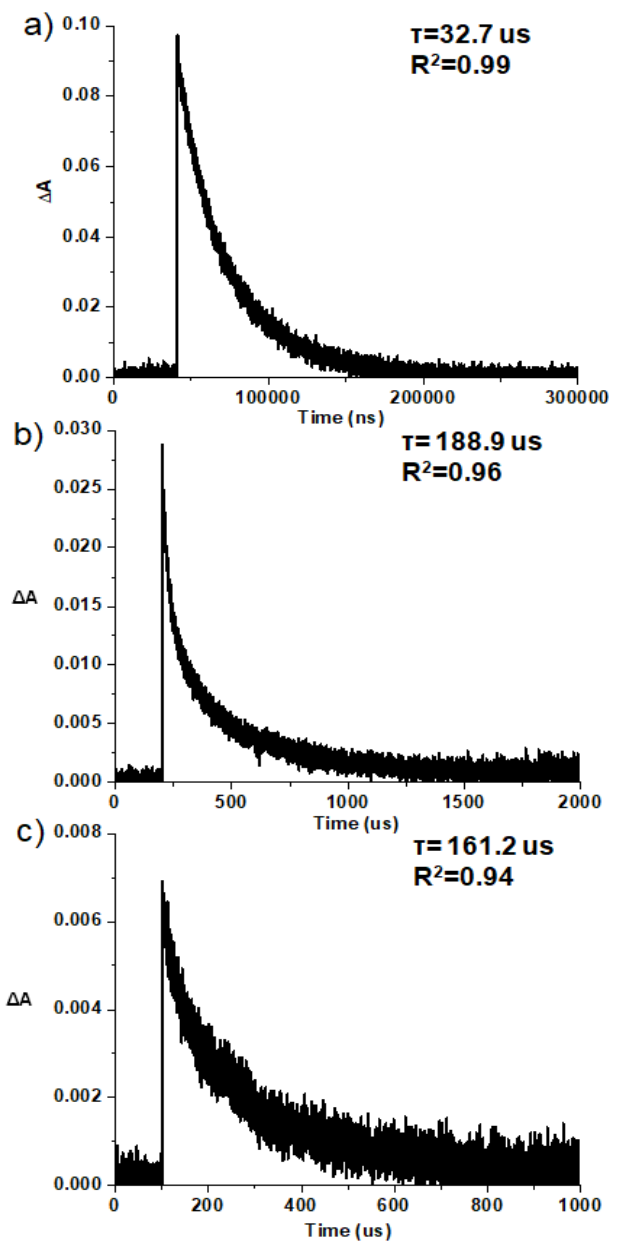

Figure S3. Transient absorption decays for Et-Au-FO (a) at $530 \mathrm{~nm}, \mathbf{A u 2}-\mathbf{F O}$ (b) at $425 \mathrm{~nm}$ and Au4-FO (c) at $475 \mathrm{~nm}$. 


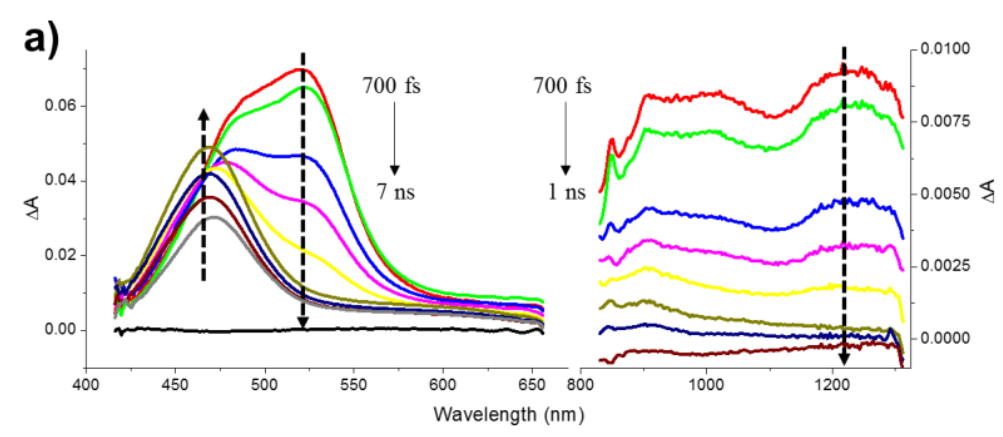

b)

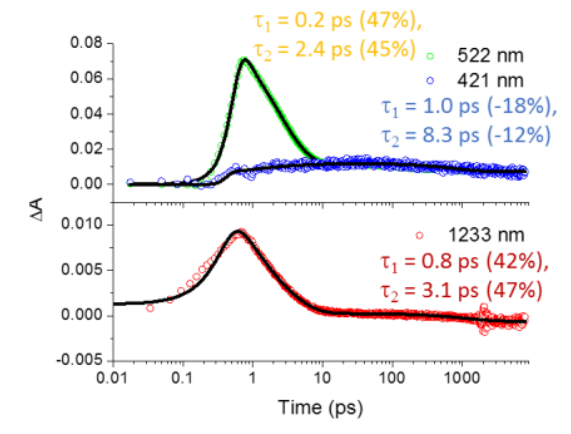

Figure S4. Ultrafast transient absorption spectra (a) and kinetic profiles (b) representing S1 decay (green and red) and T1 growth (blue) of Ph-Au-FO. $\lambda_{\text {exc }}=330 \mathrm{~nm}$. TA traces correspond to specific time after excitation: time 0 (black), < 1 ps (red), 1 ps (green), 2 ps (blue), 3 ps (magenta), 5 ps (yellow), 30 ps (dark yellow), 200 ps (navy), 1 ns (wine), 7 ns (gray).

a)

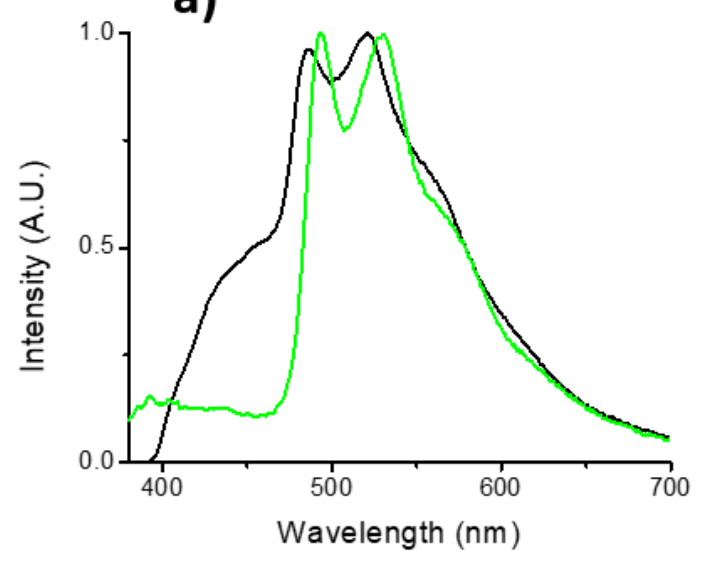

b)

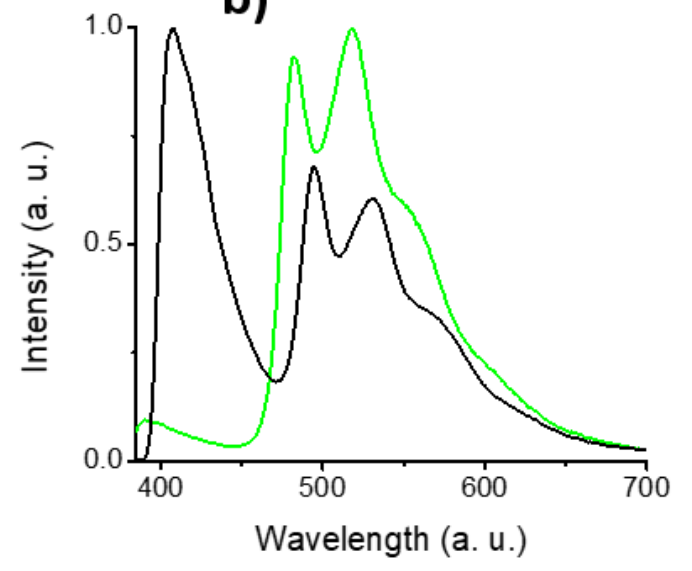

Figure S5: Photoluminescence of Auz-FO (a) and Au4-FO (b) in solution (black) and solid state emission in PMMA (1\% w: $\mathrm{w}$, green). 


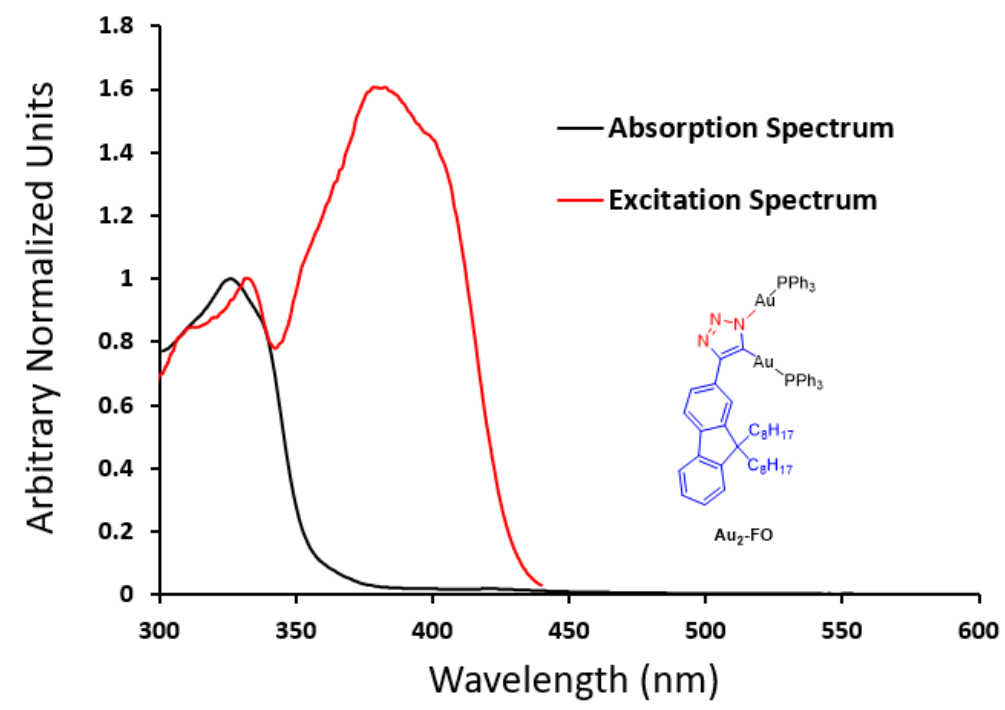

Figure S6: Absorption (black) and excitation (red) spectra of Au2-FO in air-saturated THF. For the excitation scan, emission was monitored at $460 \mathrm{~nm}$. It can be seen from the absorption spectrum that a low-absorptivity tail extends past $400 \mathrm{~nm}$.

\section{Computational Details}

All calculations were performed with the Gaussian 09 (Revision D.01) ${ }^{3}$ suite of programs using DFT methods. To mitigate computational costs, alkyl groups were reduced to methyl groups and calculations were done in vacuum. Singlet state geometries for both compounds were optimized using the B3LYP hybrid functional ${ }^{4-6}$ in conjunction with the 6-31G(d) basis set for $\mathrm{C}$ and $\mathrm{H}, 6$ $31+\mathrm{G}(\mathrm{d})$ for $\mathrm{P},{ }^{7}$ and the Stuttgart-Dresden (SSD) effective core potential (ECP) for Au. ${ }^{8}$ The results of these calculations were used as the input for TD-DFT at the same level of theory. A total of 15 vertical excitations were examined and the reported oscillator strengths, $f$, for these transitions along with the energy levels of the HOMO, LUMO, and other relevant excited states were taken from these results. These methods were repeated for triplet states, which were optimized without symmetry constraints and used the optimized geometries of the singlet states as starting geometries. All calculations were done using an ultrafine integration grid. Results of the 
geometry optimizations were fed into the MultiWFN (v. 3.6) ${ }^{9}$ software for retrieval of the atomic contributions to molecular orbitals.

Table S1: Summary of the results of DFT and TDDFT for Auz - FO and Au4-FO. $\mathbf{S}_{1}$ and $\mathrm{T}_{1}$ refer to specifically the lowest lying energy state of that given multiplicity. All values are in eV.

\begin{tabular}{|c|c|c|c|c|c|c|}
\hline & \multirow[b]{2}{*}{ НОМО } & \multirow[b]{2}{*}{ LUMO } & \multirow[b]{2}{*}{ gap } & \multirow[b]{2}{*}{$\mathbf{T}_{1}(\triangle \mathrm{SCF})$} & \multicolumn{2}{|c|}{ TDDFT } \\
\hline & & & & & $\mathbf{S}_{1}$ & $T_{1}$ \\
\hline $\mathrm{Au}_{2}-\mathrm{FO}$ & -4.34 & -0.88 & 3.46 & 2.54 & 2.95 & 2.68 \\
\hline $\mathrm{Au}_{4}-\mathrm{FO}$ & -4.76 & -1.18 & 3.58 & 2.55 & 3.10 & 2.65 \\
\hline
\end{tabular}

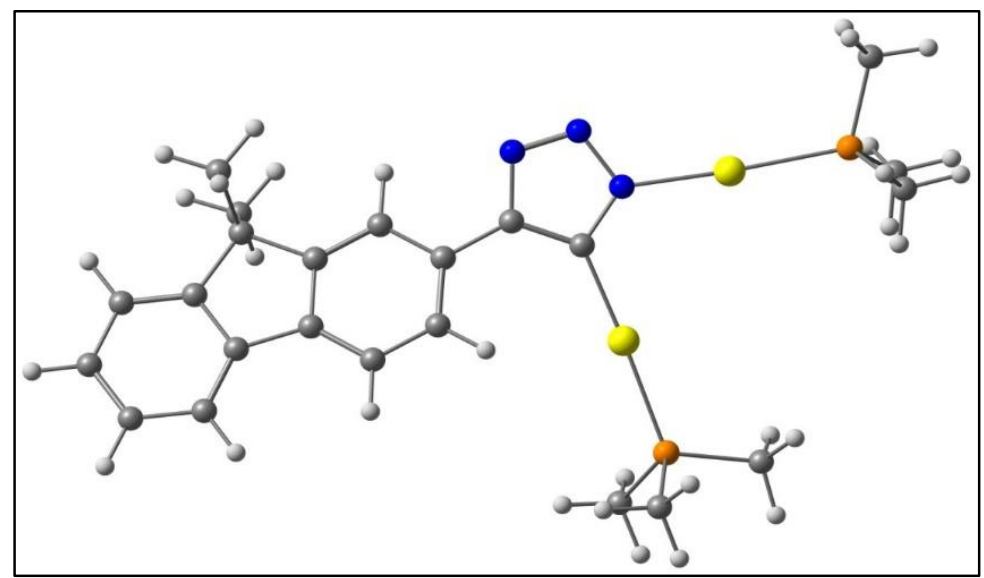

Figure S7. Optimized ground state structure for Auz-FO.

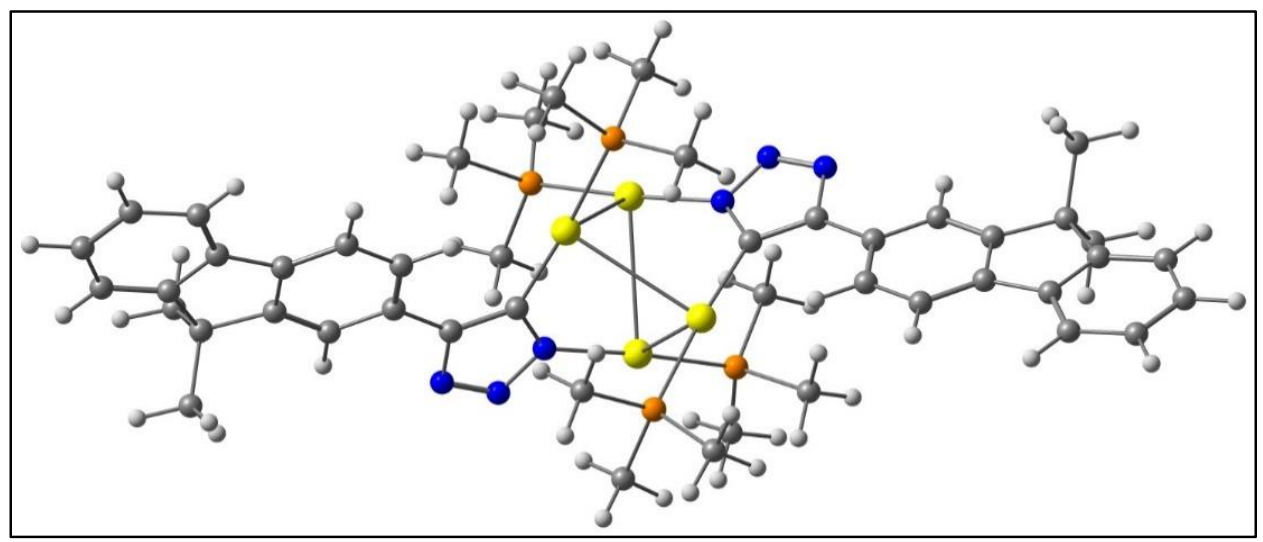

Figure S8. Optimized ground state structure for Au4-FO. 

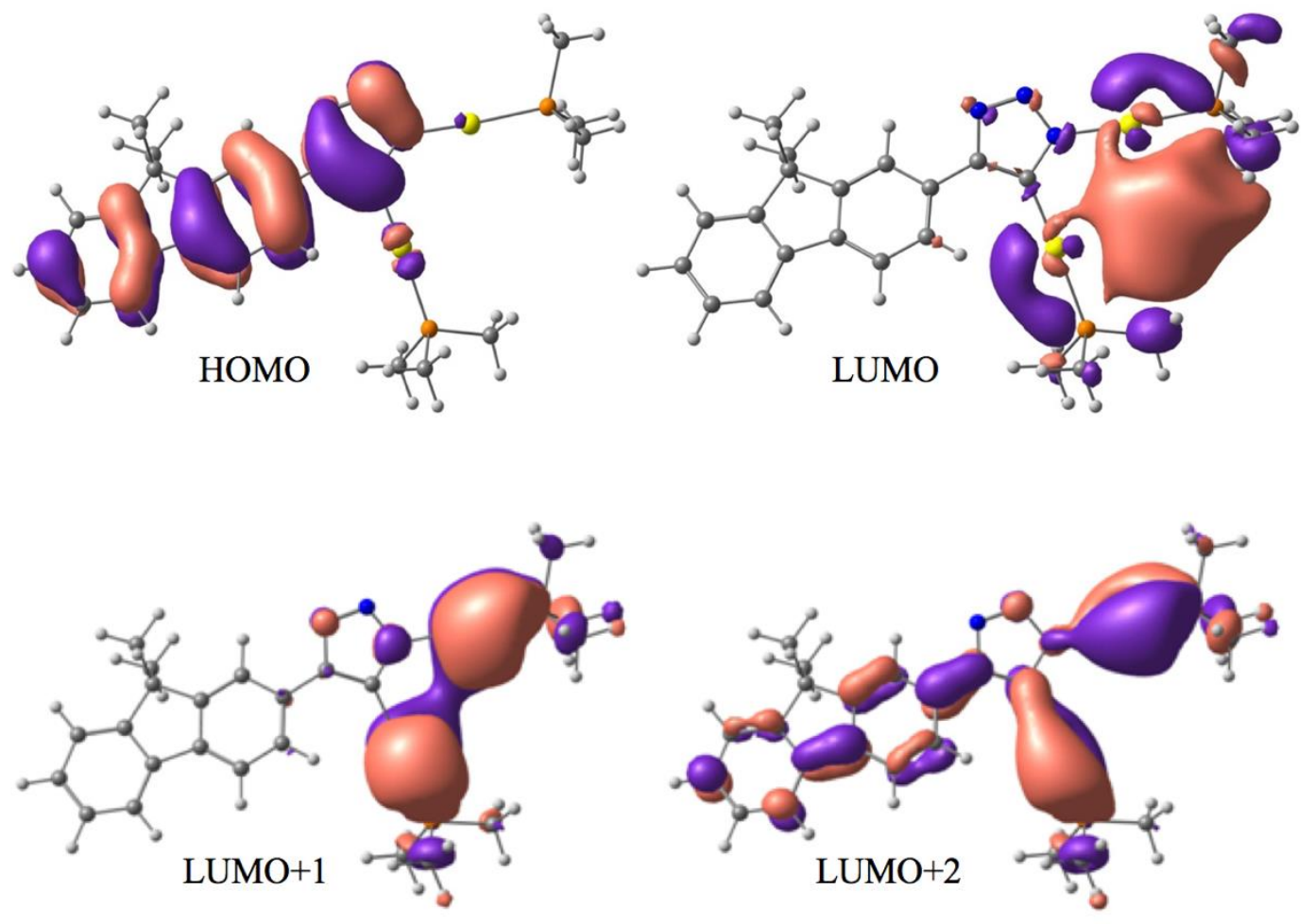

Figure S9. MOs involved in the two lowest lying excited singlet state transitions of Auz-FO
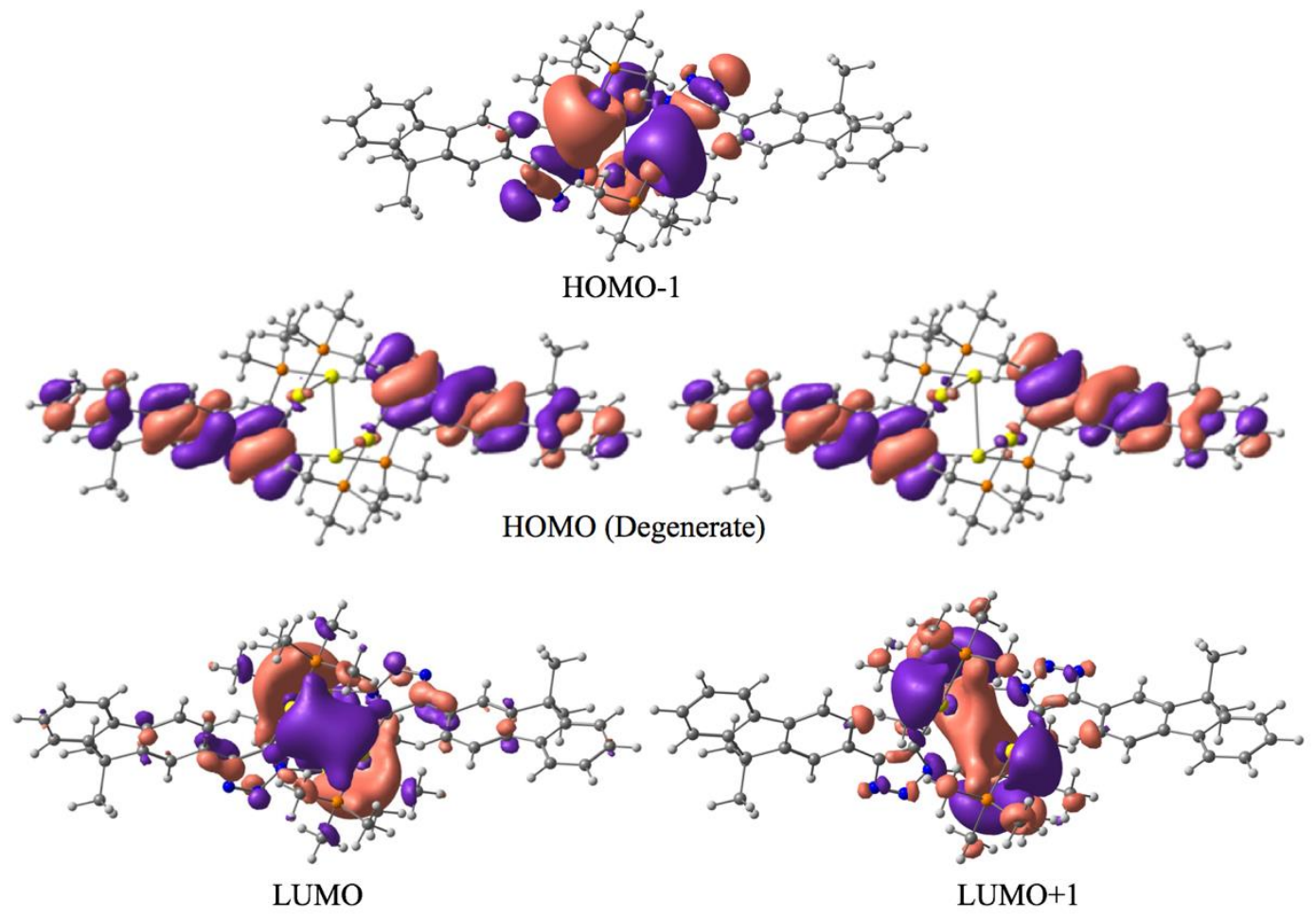

Figure S10. MOs involved in the two lowest lying excited singlet state transitions of Au4-FO 


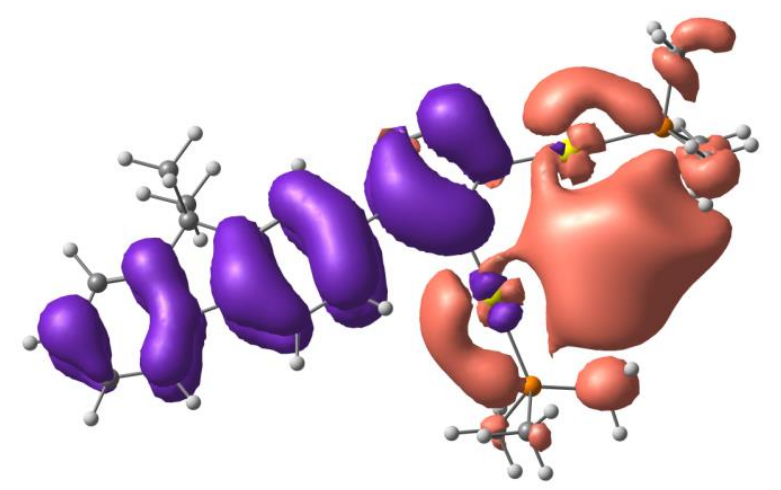

Figure S11. CDD of excited state $\mathrm{S}_{1}$ for $\mathbf{A u}_{2}-\mathbf{F O}$ with oscillator strength, $f=0.0001$ where purple represents where charge came from and pink represents were charge moved to.

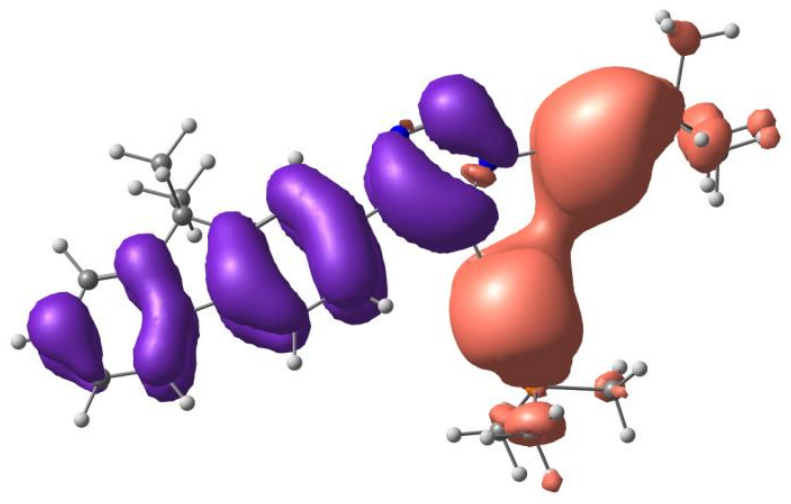

Figure S12. CDD of excited state $\mathrm{S}_{2}$ for Auz-FO with oscillator strength, $f=0.0462$

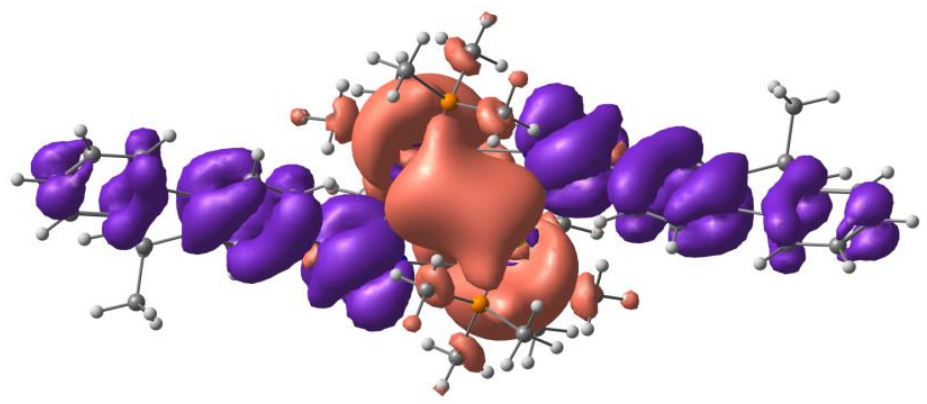

Figure S13. $\mathrm{CDD}$ of excited state $\mathrm{S}_{1}$ for Au4-FO with oscillator strength, $f=0.327$

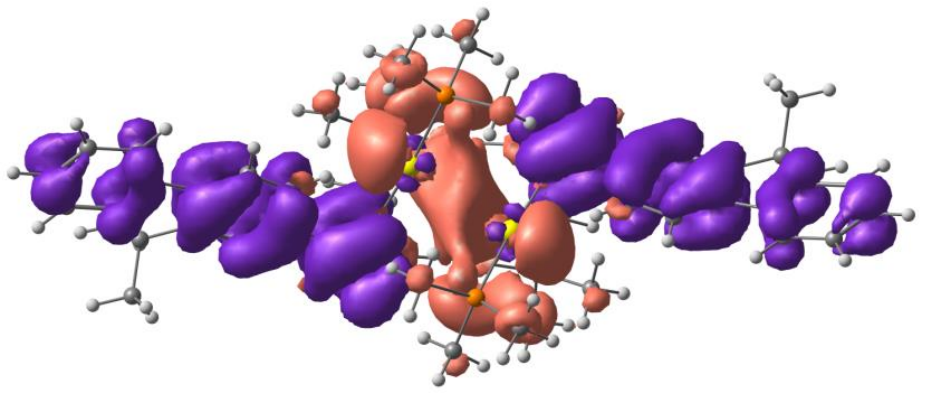

Figure S14. CDD of excited state $\mathrm{S}_{2}$ for Au4-FO with oscillator strength, $f=0.0084$ 

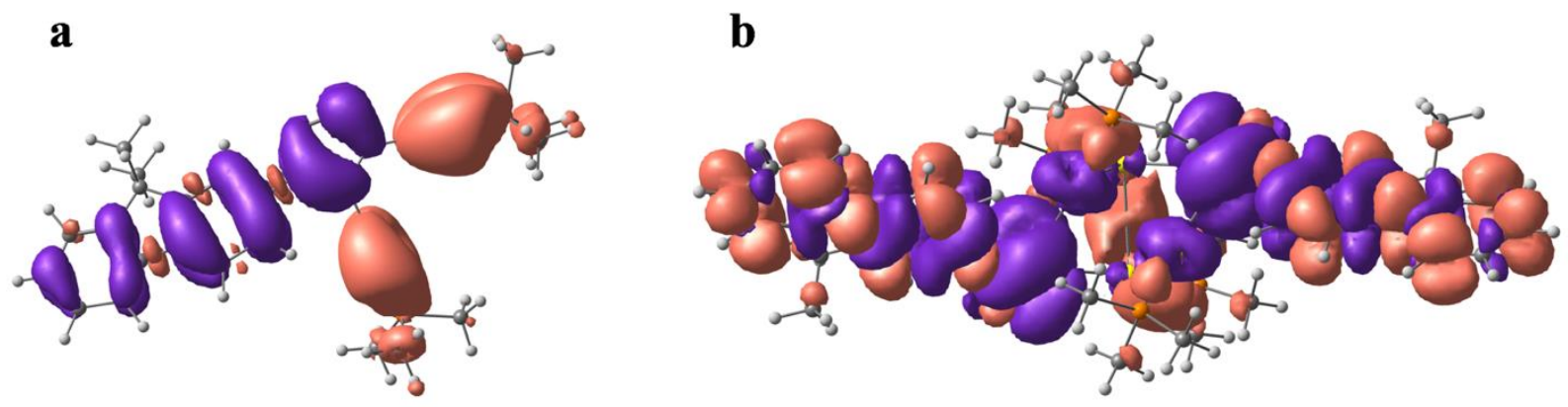

Figure S15. CDDs for higher ordered singlet excitations with large oscillator strengths. (a) Excited state $\mathrm{S}_{4}$ of $\mathbf{A u}_{2}-\mathbf{F O}$ with an energy of $3.44 \mathrm{eV}$ and an oscillator strength of 0.2868 , (b) Excited state $\mathrm{S}_{5}$ of Au4-FO with an energy of $3.78 \mathrm{eV}$ and an oscillator strength of 0.8288

Table S2: Atomic coordinates in angstroms of geometry optimized structures used as input for TDDFT calculation

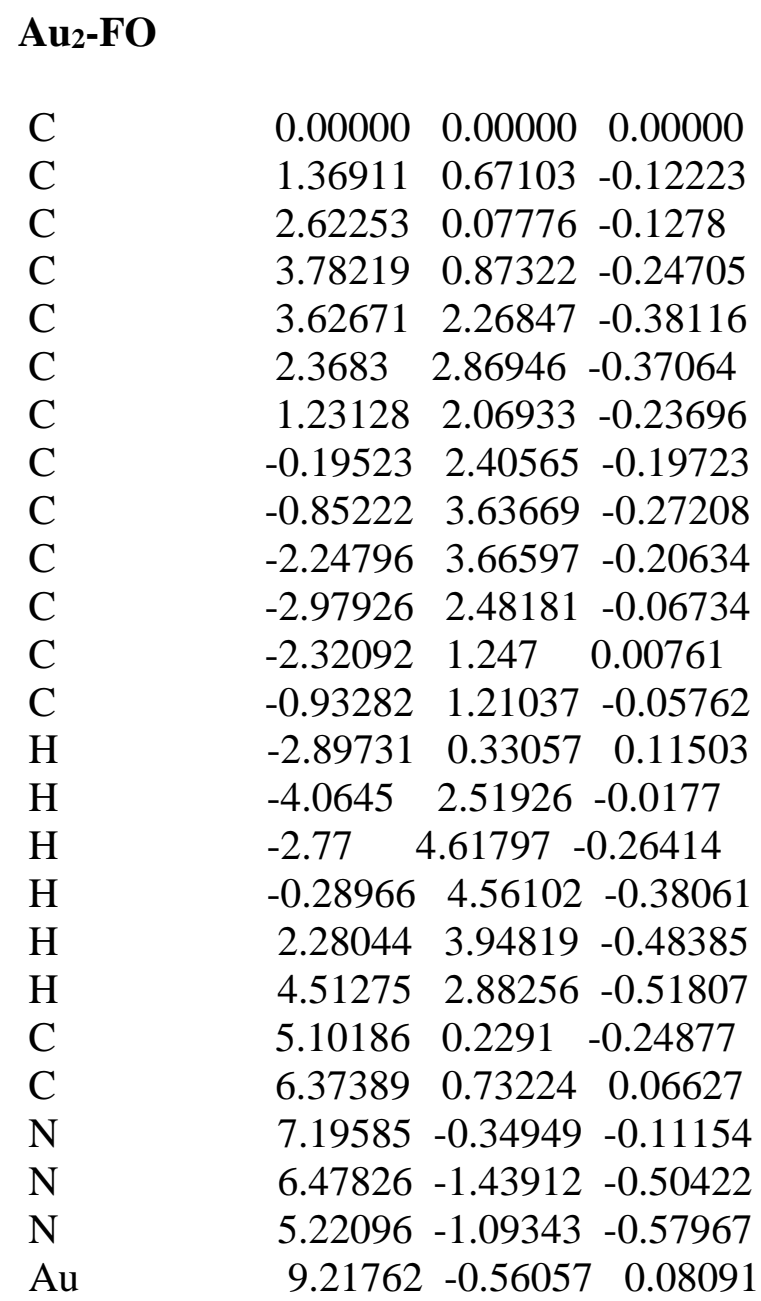




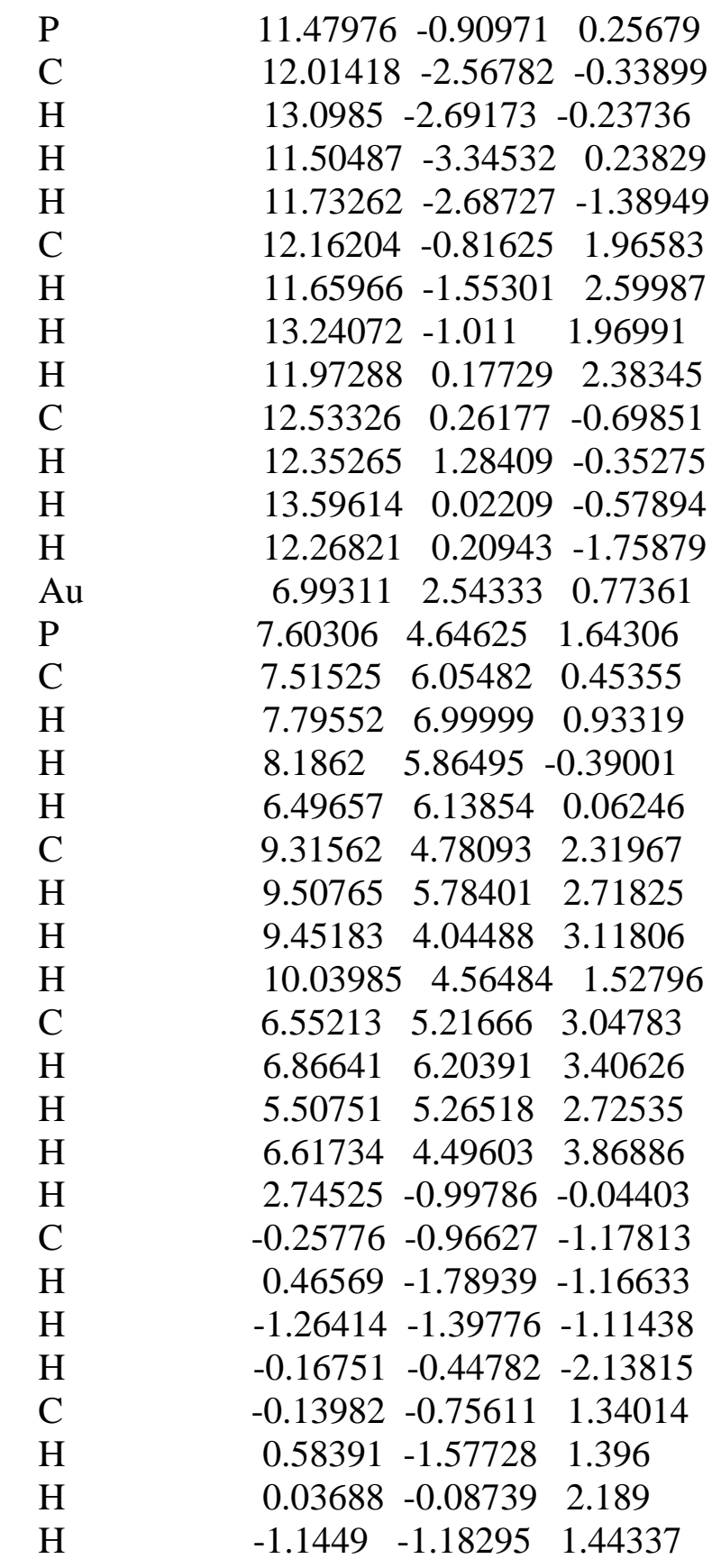

\section{Au4-FO}

$\begin{array}{llll}\mathrm{C} & 0.00000 & 0.00000 & 0.00000 \\ \mathrm{C} & 1.25634 & 0.62552 & 0.60832 \\ \mathrm{C} & 2.53048 & 0.08613 & 0.69616 \\ \mathrm{C} & 3.57474 & 0.82259 & 1.29868 \\ \mathrm{C} & 3.27712 & 2.10311 & 1.81023 \\ \mathrm{C} & 1.99678 & 2.65057 & 1.72001 \\ \mathrm{C} & 0.97847 & 1.91152 & 1.11465\end{array}$




\begin{tabular}{|c|c|c|c|}
\hline $\mathrm{C}$ & -0.43679 & 2.21407 & 0.87917 \\
\hline $\mathrm{C}$ & -1.19838 & 3.34438 & 1.18705 \\
\hline $\mathrm{C}$ & -2.55183 & 3.3643 & 0.84001 \\
\hline $\mathrm{C}$ & -3.13736 & 2.27034 & 0.19411 \\
\hline $\mathrm{C}$ & -2.374 & $1.13675-0$ & 0.11464 \\
\hline $\mathrm{C}$ & -1.02681 & 1.11004 & 0.22774 \\
\hline $\mathrm{H}$ & -2.83802 & 0.29051 & -0.61661 \\
\hline $\mathrm{H}$ & -4.19135 & 2.29962 & -0.06975 \\
\hline $\mathrm{H}$ & -3.15513 & 4.23776 & 1.07428 \\
\hline $\mathrm{H}$ & -0.74921 & 4.1979 & 1.68929 \\
\hline $\mathrm{H}$ & 1.80135 & 3.64046 & 2.12735 \\
\hline $\mathrm{H}$ & 4.06834 & 2.67372 & 2.28915 \\
\hline $\mathrm{C}$ & 4.92049 & 0.2291 & 1.37596 \\
\hline $\mathrm{C}$ & 6.17701 & 0.79021 & 1.67798 \\
\hline $\mathrm{N}$ & 7.03668 & -0.27434 & 1.56131 \\
\hline $\mathrm{N}$ & 6.35476 & -1.40134 & 1.21145 \\
\hline $\mathrm{N}$ & 5.08602 & -1.10137 & 1.09737 \\
\hline $\mathrm{Au}$ & 9.10503 & -0.50585 & 1.72631 \\
\hline $\mathrm{P}$ & 11.36793 & -0.9735 & 1.83154 \\
\hline $\mathrm{C}$ & 11.76008 & -2.72411 & 1.40186 \\
\hline $\mathrm{H}$ & 12.83958 & $3-2.90633$ & $\begin{array}{ll}3 & 1.46082\end{array}$ \\
\hline $\mathrm{H}$ & 11.24297 & $7 \quad-3.3995$ & 2.09026 \\
\hline $\mathrm{H}$ & 11.41334 & $4-2.9432$ & 0.38739 \\
\hline $\mathrm{C}$ & 12.148 & -0.74393 & 3.48024 \\
\hline $\mathrm{H}$ & 11.65145 & $5-1.38113$ & $3 \quad 4.21845$ \\
\hline $\mathrm{H}$ & 13.21247 & $7-1.00218$ & $\begin{array}{ll}8 & 3.43711\end{array}$ \\
\hline $\mathrm{H}$ & 12.03623 & $3 \quad 0.29912$ & 23.78905 \\
\hline $\mathrm{C}$ & 12.43359 & 0.00619 & 0.69809 \\
\hline $\mathrm{H}$ & 12.33187 & $7 \quad 1.07331$ & 0.91678 \\
\hline $\mathrm{H}$ & 13.48199 & -0.29307 & $\begin{array}{ll}7 & 0.81294\end{array}$ \\
\hline $\mathrm{H}$ & 12.12247 & $7-0.1633$ & -0.33741 \\
\hline $\mathrm{Au}$ & 8.9832 & 1.57289 & 4.14424 \\
\hline $\mathrm{Au}$ & 6.74044 & 2.72756 & 2.12346 \\
\hline $\mathrm{P}$ & 7.20518 & 5.01131 & 2.58003 \\
\hline $\mathrm{C}$ & 5.69356 & 6.07382 & 2.55811 \\
\hline $\mathrm{H}$ & 5.94698 & 7.12142 & 2.75928 \\
\hline $\mathrm{H}$ & 5.20554 & 6.00451 & 1.58085 \\
\hline $\mathrm{H}$ & 4.98491 & 5.72592 & 3.31639 \\
\hline $\mathrm{C}$ & 8.33402 & 5.86646 & 1.40189 \\
\hline $\mathrm{H}$ & 8.46087 & 6.91754 & 1.68693 \\
\hline $\mathrm{H}$ & 9.30842 & 5.36944 & 1.3981 \\
\hline $\mathrm{H}$ & 7.91856 & 5.81676 & 0.39041 \\
\hline $\mathrm{C}$ & 7.95378 & 5.38481 & 4.22087 \\
\hline $\mathrm{H}$ & 8.09384 & 6.46503 & 4.34517 \\
\hline $\mathrm{H}$ & 7.30495 & 5.01109 & 5.01927 \\
\hline $\mathrm{H}$ & 8.9207 & 4.87954 & 4.29568 \\
\hline
\end{tabular}




\begin{tabular}{|c|c|c|c|}
\hline $\mathrm{Au}$ & 9.23535 & 2.27608 & 0.18924 \\
\hline $\mathrm{N}$ & 10.44772 & 2.87177 & $7 \quad 1.78117$ \\
\hline $\mathrm{C}$ & 10.42017 & 2.66521 & 3.13851 \\
\hline $\mathrm{C}$ & 11.58662 & 3.31332 & 3.59048 \\
\hline $\mathrm{C}$ & 12.16788 & 3.46013 & 34.93575 \\
\hline $\mathrm{C}$ & 11.44529 & 3.17124 & 46.11234 \\
\hline $\mathrm{C}$ & 12.01578 & 3.31265 & 7.3779 \\
\hline $\mathrm{H}$ & 11.42877 & 3.08363 & 38.26501 \\
\hline $\mathrm{C}$ & 13.33435 & 3.75875 & 7.48726 \\
\hline $\mathrm{C}$ & 14.18603 & 4.00362 & 8.65542 \\
\hline $\mathrm{C}$ & 13.93489 & 3.85853 & 310.02227 \\
\hline $\mathrm{C}$ & 14.94726 & 4.16987 & $7 \quad 10.93376$ \\
\hline $\mathrm{H}$ & 14.7642 & 4.06148 & 11.99984 \\
\hline $\mathrm{C}$ & 16.19397 & 4.62006 & $5 \quad 10.48671$ \\
\hline $\mathrm{H}$ & 16.97211 & 4.85875 & $5 \quad 11.20706$ \\
\hline $\mathrm{C}$ & 16.44606 & 4.76575 & 9.1162 \\
\hline $\mathrm{H}$ & 17.41845 & 5.11701 & 18.77784 \\
\hline $\mathrm{C}$ & 15.44334 & 4.45795 & 8.20368 \\
\hline $\mathrm{C}$ & 15.47733 & 4.53629 & 6.6769 \\
\hline $\mathrm{C}$ & 14.06722 & 4.06172 & 6.32172 \\
\hline $\mathrm{C}$ & 13.49858 & 3.91643 & 3.06565 \\
\hline $\mathrm{H}$ & 14.05161 & 4.15064 & $4 \quad 4.16142$ \\
\hline $\mathrm{C}$ & 15.72099 & 5.98315 & 6.19184 \\
\hline $\mathrm{H}$ & 14.97028 & 6.66657 & $7 \quad 6.60177$ \\
\hline $\mathrm{H}$ & 16.7116 & 6.33585 & 6.50321 \\
\hline $\mathrm{H}$ & 15.67049 & 6.03677 & $7 \quad 5.09833$ \\
\hline $\mathrm{C}$ & 16.55293 & 3.59624 & 6.08797 \\
\hline $\mathrm{H}$ & 16.39929 & 2.56489 & 6.42245 \\
\hline $\mathrm{H}$ & 17.55659 & 3.9106 & 6.39853 \\
\hline $\mathrm{H}$ & 16.51837 & 3.60996 & $5 \quad 4.99249$ \\
\hline $\mathrm{H}$ & 12.96775 & 3.50941 & 10.3762 \\
\hline $\mathrm{H}$ & 10.41612 & 2.83313 & 36.02627 \\
\hline $\mathrm{N}$ & 12.23713 & 3.85435 & 52.51376 \\
\hline $\mathrm{N}$ & 11.55135 & 3.5906 & 1.43079 \\
\hline $\mathrm{P}$ & 8.04756 & 1.70538 & -1.71205 \\
\hline $\mathrm{C}$ & 7.82468 & -0.09691 & -1.99858 \\
\hline $\mathrm{H}$ & 7.29014 & -0.54701 & -1.15684 \\
\hline $\mathrm{H}$ & 8.8032 & -0.57996 & -2.08182 \\
\hline $\mathrm{H}$ & 7.26003 & $-0.265-$ & -2.92313 \\
\hline $\mathrm{C}$ & 6.34117 & 2.38233 & -1.80988 \\
\hline $\mathrm{H}$ & 5.75741 & 2.00939 & -0.96376 \\
\hline $\mathrm{H}$ & 6.37094 & 3.47501 & -1.75786 \\
\hline $\mathrm{H}$ & 5.86366 & 2.0775 & -2.74833 \\
\hline $\mathrm{C}$ & 8.84512 & 2.30312 & -3.26436 \\
\hline $\mathrm{H}$ & 9.84972 & 1.87831 & -3.35219 \\
\hline $\mathrm{H}$ & 8.93901 & 3.39302 & -3.23701 \\
\hline
\end{tabular}




$\begin{array}{lccc}\mathrm{H} & 8.25387 & 2.01403 & -4.14122 \\ \mathrm{P} & 7.4516 & 0.32225 & 5.4597 \\ \mathrm{C} & 5.71167 & 0.92587 & 5.48854 \\ \mathrm{H} & 5.09757 & 0.30361 & 6.15008 \\ \mathrm{H} & 5.68336 & 1.96219 & 5.83971 \\ \mathrm{H} & 5.3051 & 0.89273 & 4.47399 \\ \mathrm{C} & 7.90702 & 0.27699 & 7.25002 \\ \mathrm{H} & 7.18709 & -0.31916 & 7.82316 \\ \mathrm{H} & 7.92884 & 1.29454 & 7.65291 \\ \mathrm{H} & 8.90529 & -0.15595 & 7.3682 \\ \mathrm{C} & 7.26863 & -1.45963 & 5.03013 \\ \mathrm{H} & 6.5607 & -1.94721 & 5.71071 \\ \mathrm{H} & 6.91124 & -1.55672 & 4.0009 \\ \mathrm{H} & 8.23997 & -1.95869 & 5.10501 \\ \mathrm{H} & 2.75556 & -0.90425 & 0.31305 \\ \mathrm{C} & 0.18898 & -0.29342 & -1.50517 \\ \mathrm{H} & 0.97712 & -1.04011 & -1.65598 \\ \mathrm{H} & -0.73636 & -0.68516 & -1.94436 \\ \mathrm{H} & 0.46836 & 0.61414 & -2.05054 \\ \mathrm{C} & -0.39686 & -1.29592 & 0.74245 \\ \mathrm{H} & 0.38251 & -2.05832 & 0.63065 \\ \mathrm{H} & -0.53937 & -1.10817 & 1.81162 \\ \mathrm{H} & -1.33118 & -1.70442 & 0.33894 \\ & & & \end{array}$




\section{NMR Spectra}

\section{NMR Spectra of Et-Au-FO}

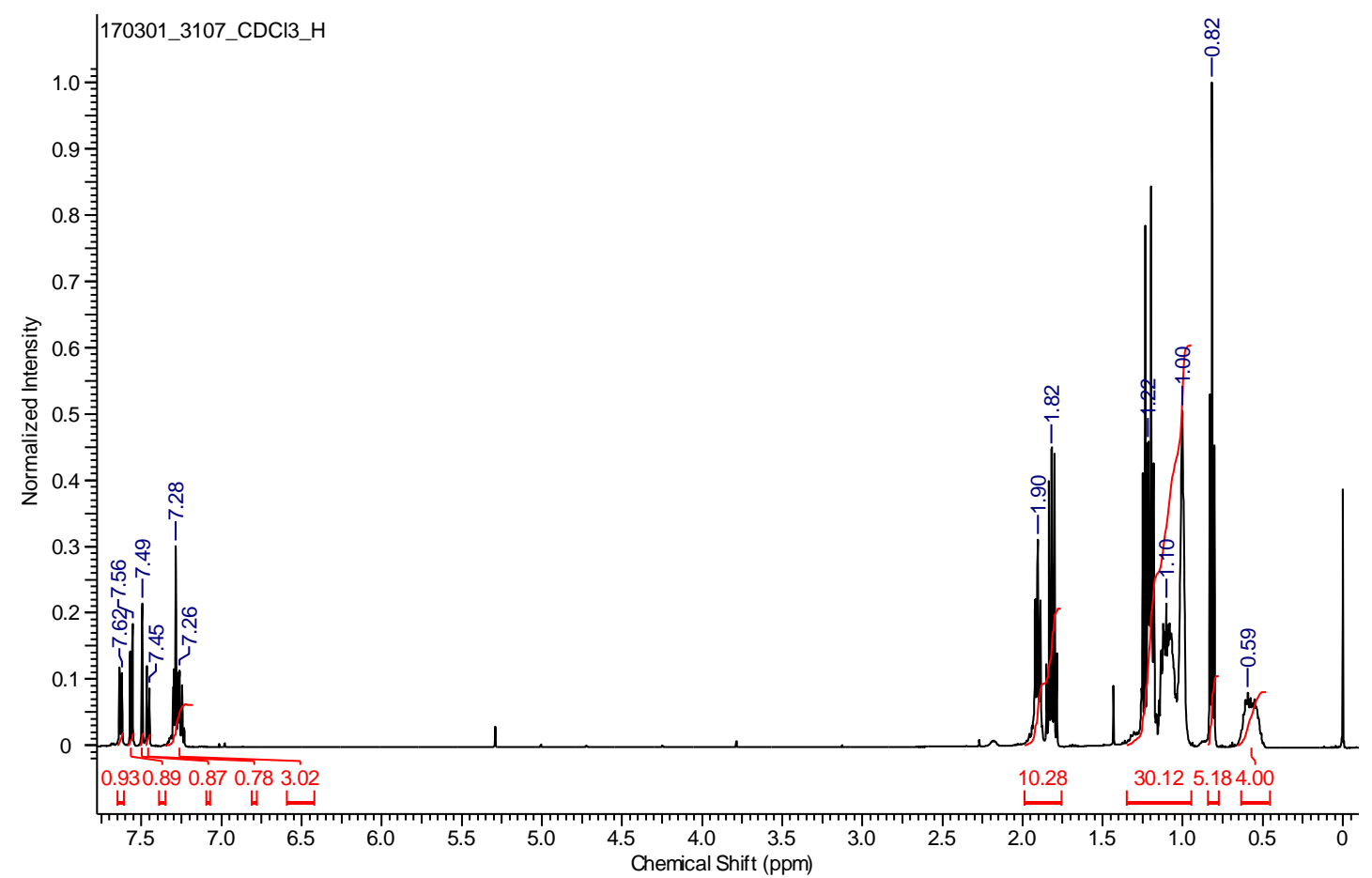

Figure S16. ${ }^{1} \mathrm{H}$ NMR spectrum of Et-Au-FO (500 $\left.\mathrm{MHz}, \mathrm{CDCl}_{3}\right)$.

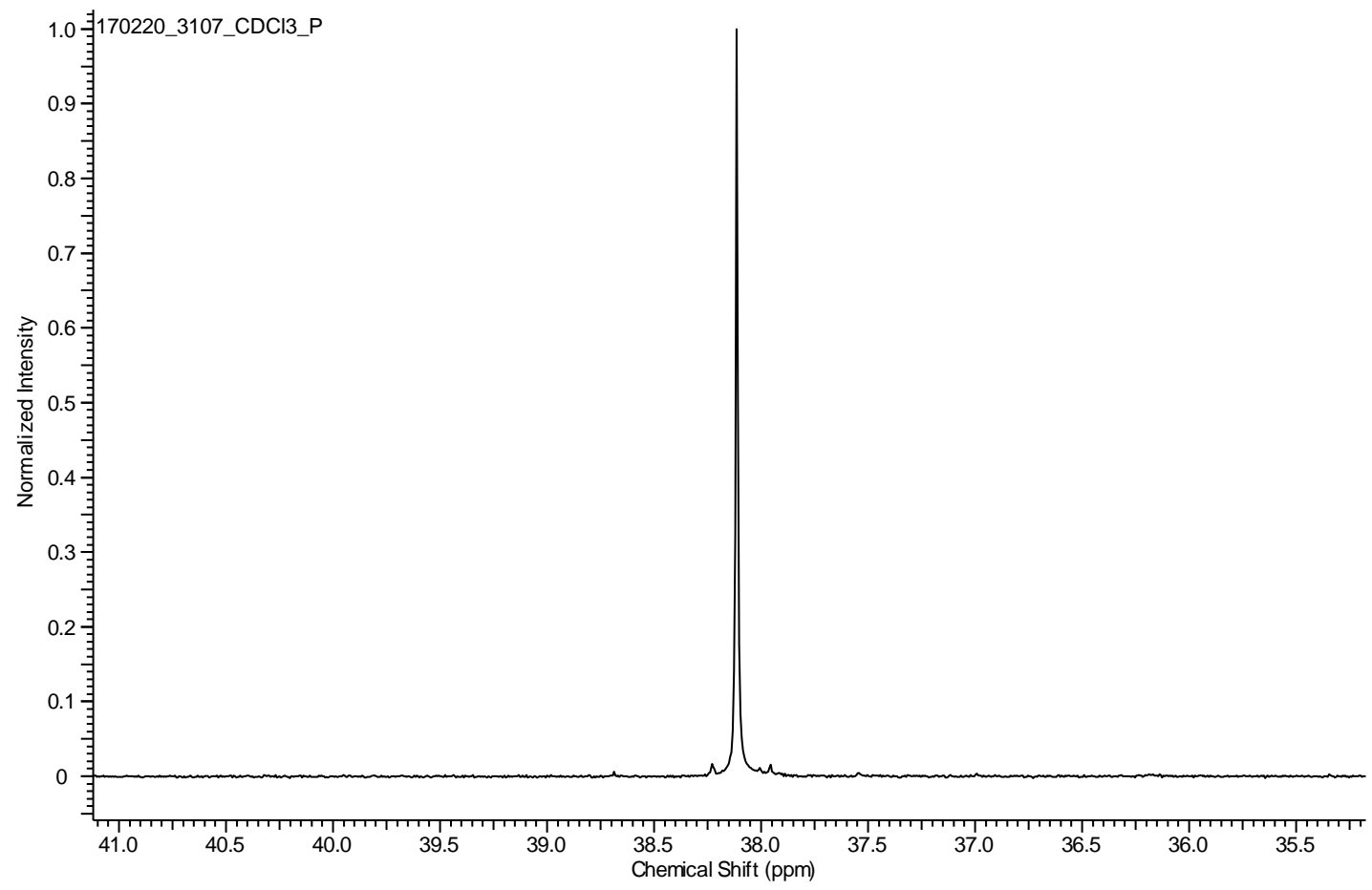

Figure S17. ${ }^{31} \mathrm{P}$ NMR spectrum of Et-Au-FO $\left(121 \mathrm{MHz}, \mathrm{CDCl}_{3}\right)$. 


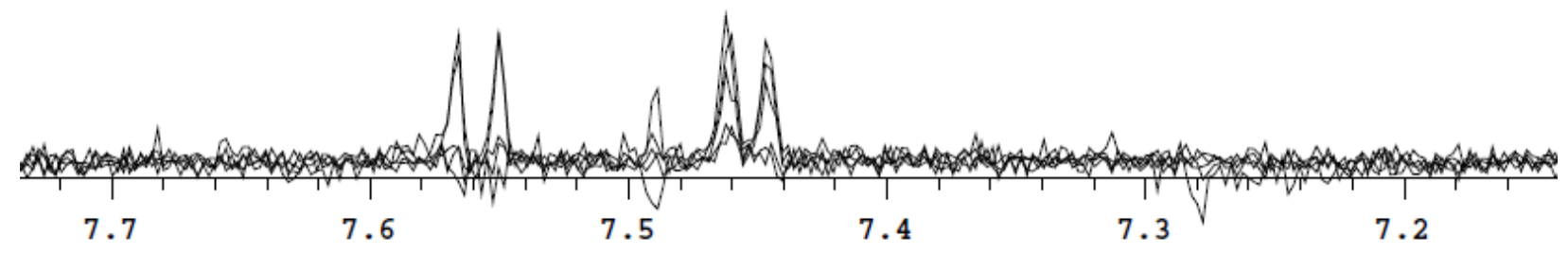

Figure S18. TOCSY 1D spectra of Et-Au-FO with selective excitation at $7.46 \mathrm{ppm}$.

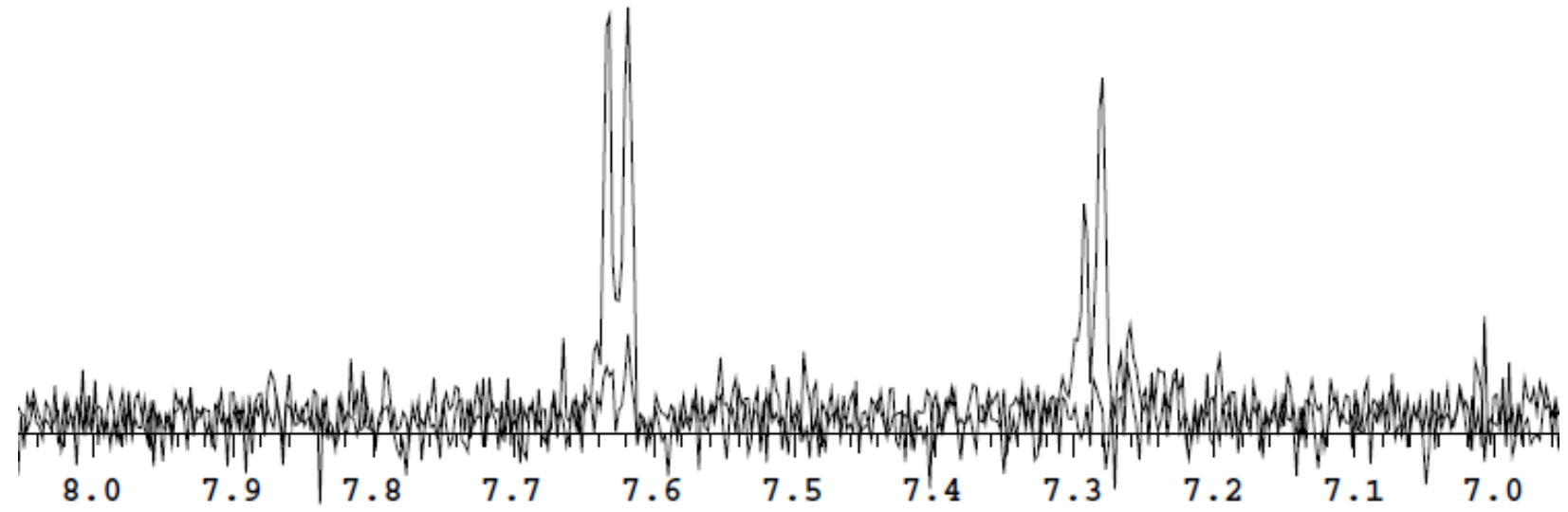

Figure S19. TOCSY 1D spectra of Et-Au-FO with selective excitation at $7.63 \mathrm{ppm}$.

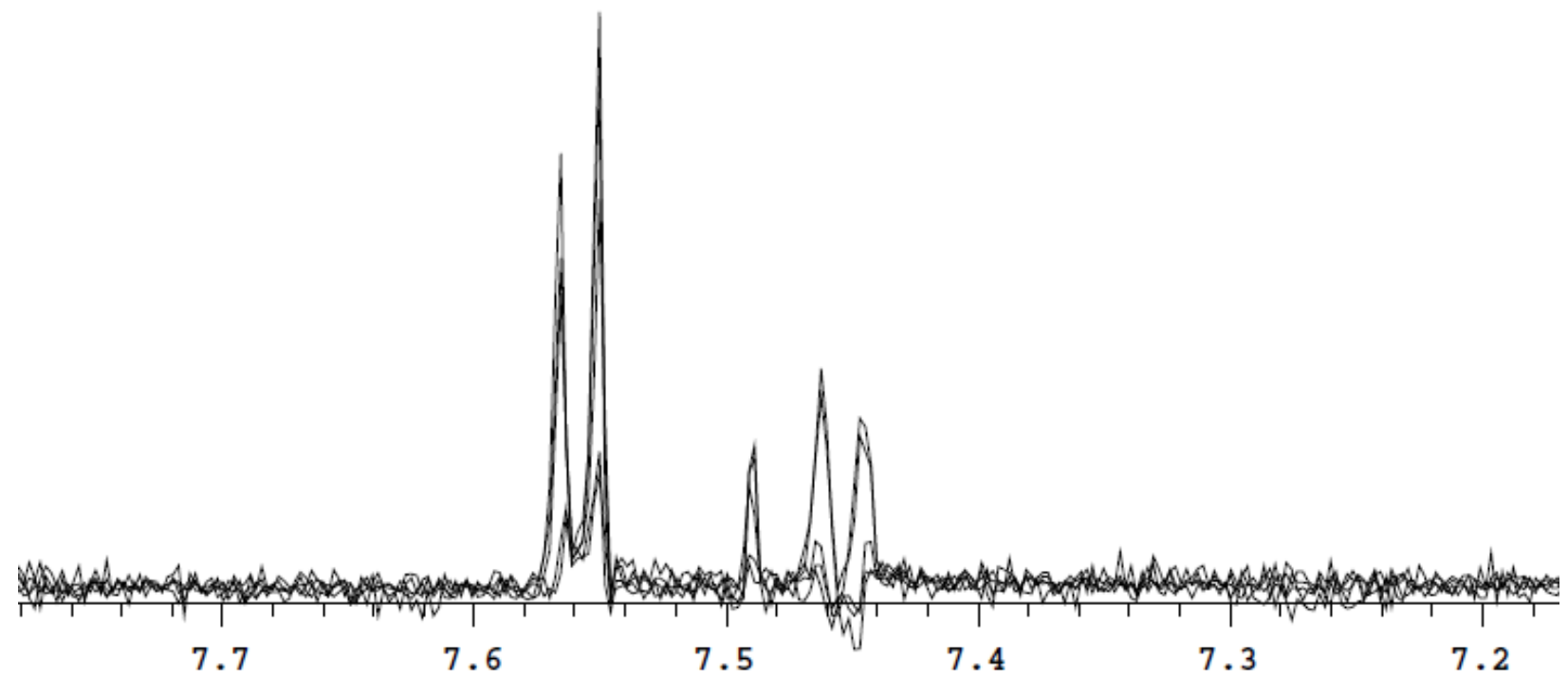

Figure S20. TOCSY 1D spectra of Et-Au-FO with selective excitation at $7.56 \mathrm{ppm}$. 


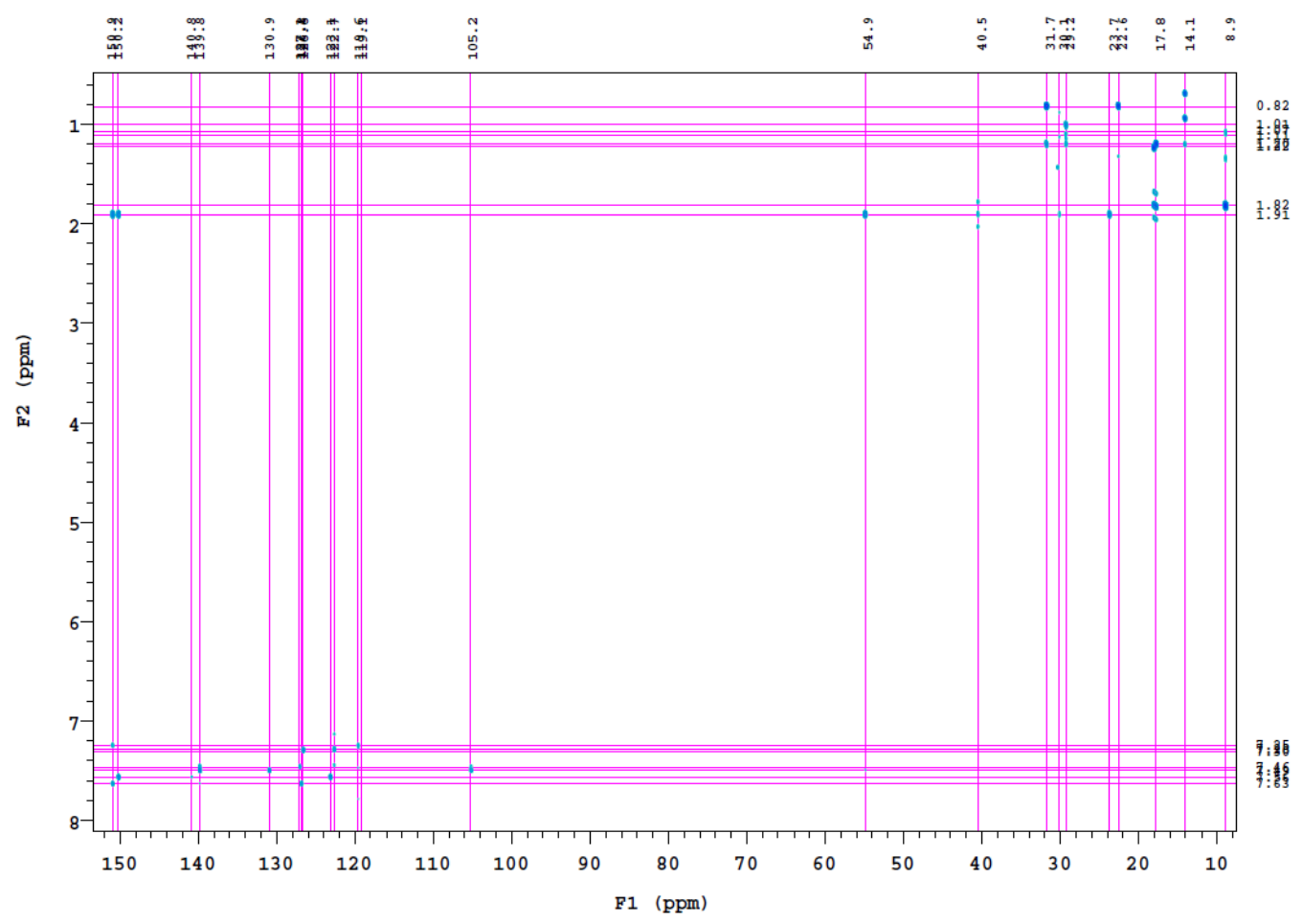

Figure S21. ${ }^{1} \mathrm{H}-{ }^{13} \mathrm{C}$ gHMBC spectrum of Et-Au-FO $\left(500 \mathrm{MHz} / 125 \mathrm{MHz}, \mathrm{CDCl}_{3}\right)$.

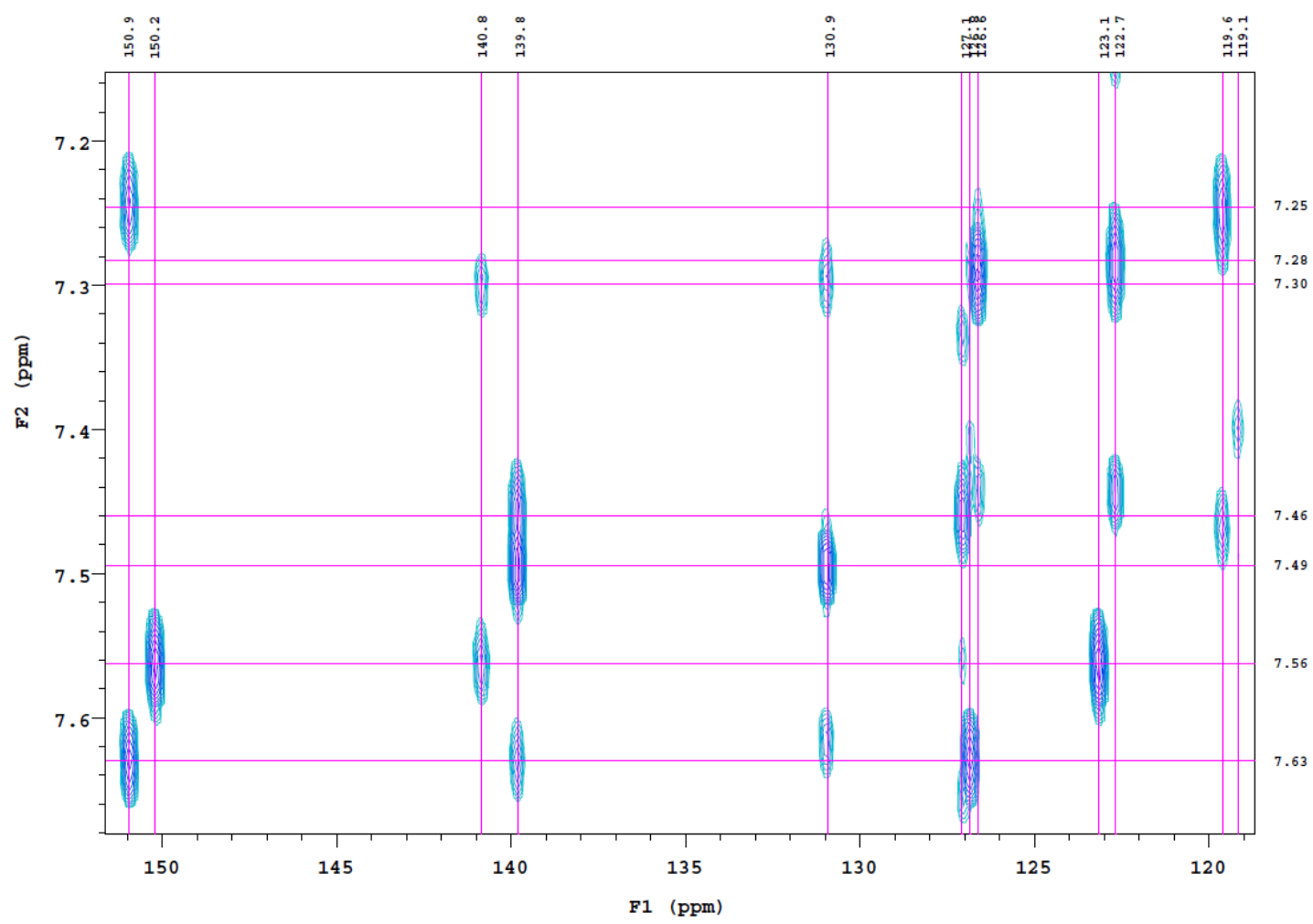

Figure S22. ${ }^{1} \mathrm{H}_{-}{ }^{13} \mathrm{C}$ gHMBC spectrum of Et-Au-FO $\left(500 \mathrm{MHz} / 125 \mathrm{MHz}, \mathrm{CDCl}_{3}\right)$, (expanded region F1 119-151). 


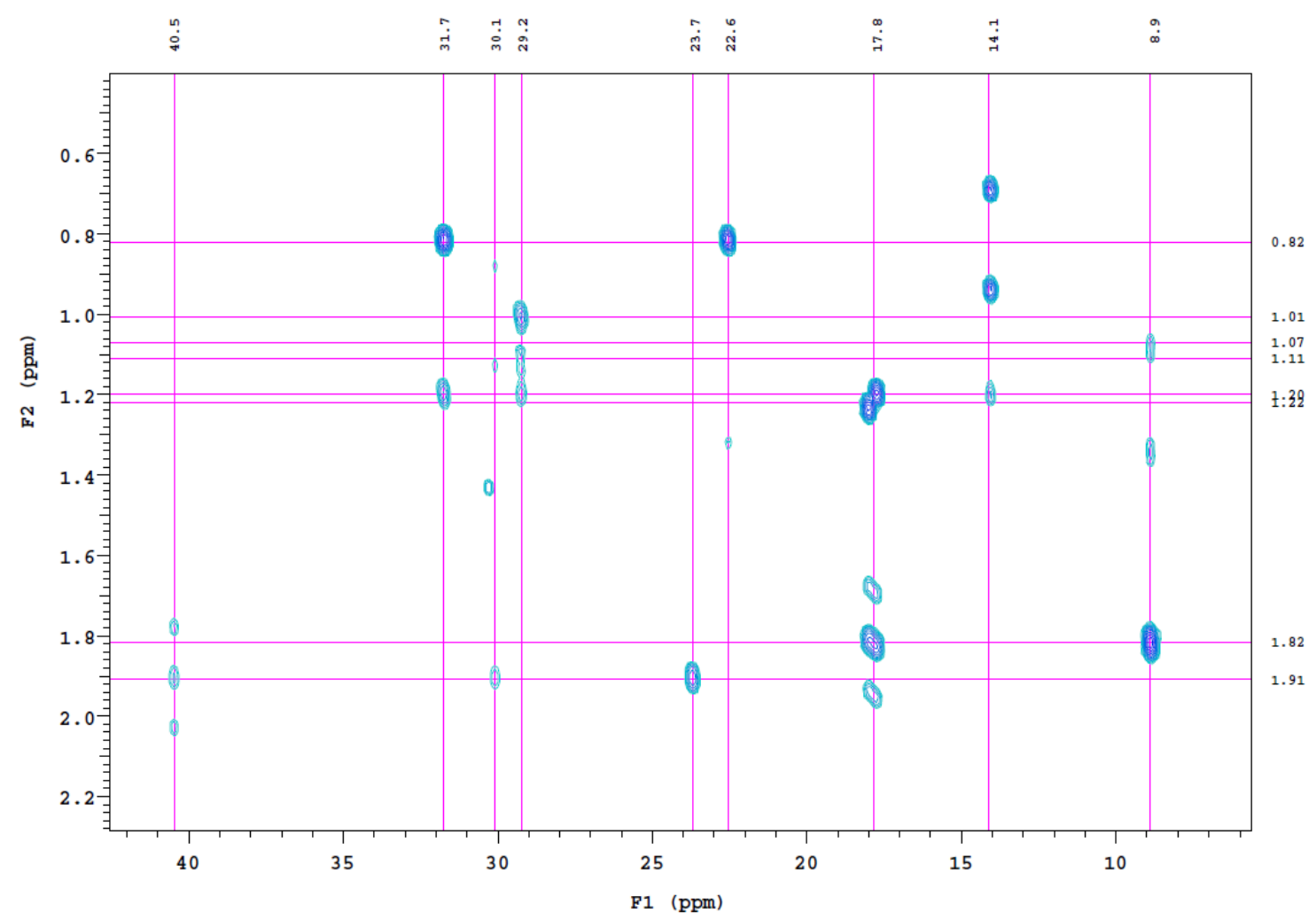

Figure S23. ${ }^{1} \mathrm{H}^{-13} \mathrm{C}$ gHMBC spectrum of Et-Au-FO $\left(500 \mathrm{MHz} / 125 \mathrm{MHz}, \mathrm{CDCl}_{3}\right)$, (expanded region F1 8-42).

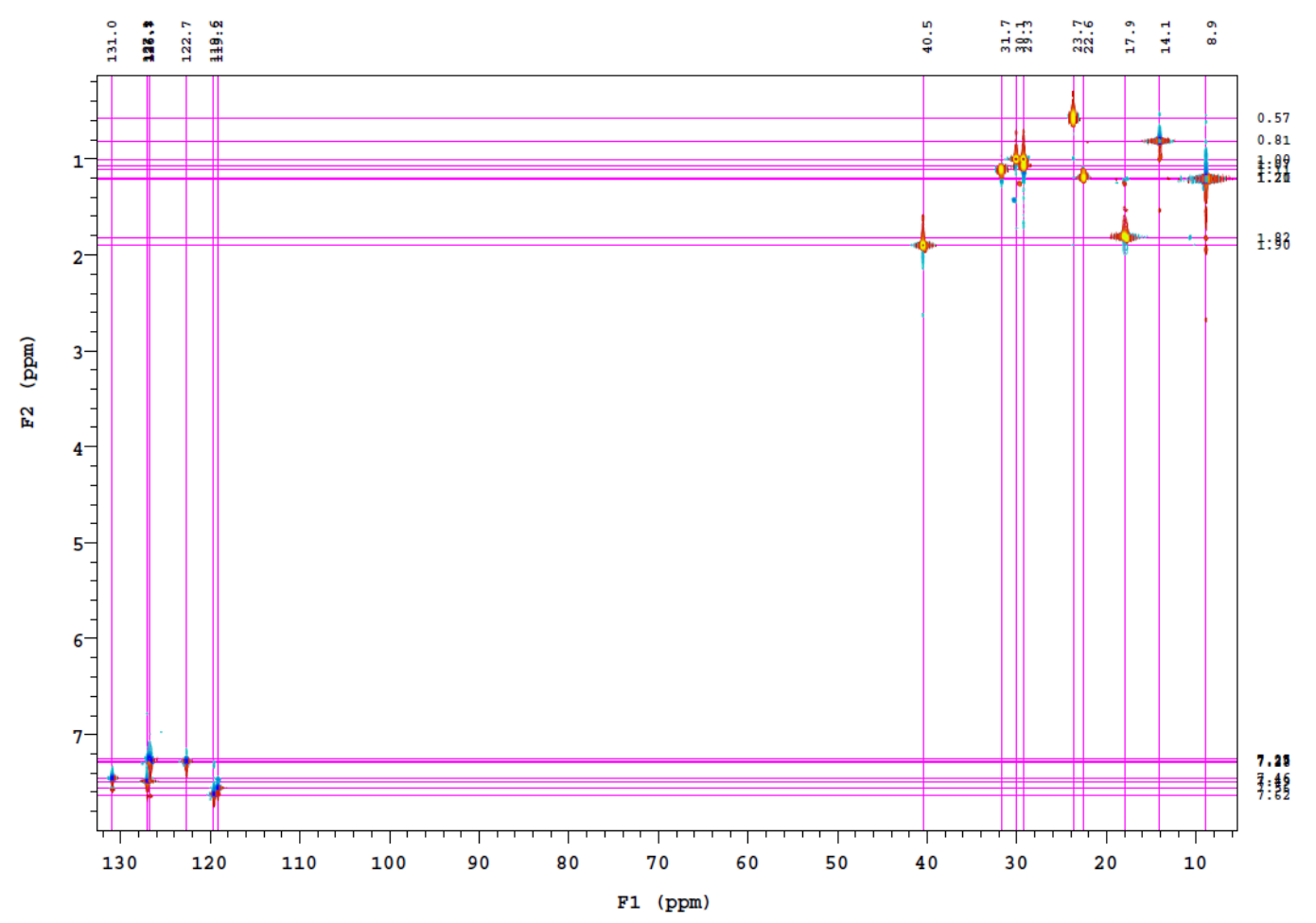

Figure S24. ${ }^{1} \mathrm{H}-{ }^{13} \mathrm{C}$ gHSQC spectrum of Et-Au-FO $\left(500 \mathrm{MHz} / 125 \mathrm{MHz}, \mathrm{CDCl}_{3}\right)$. 


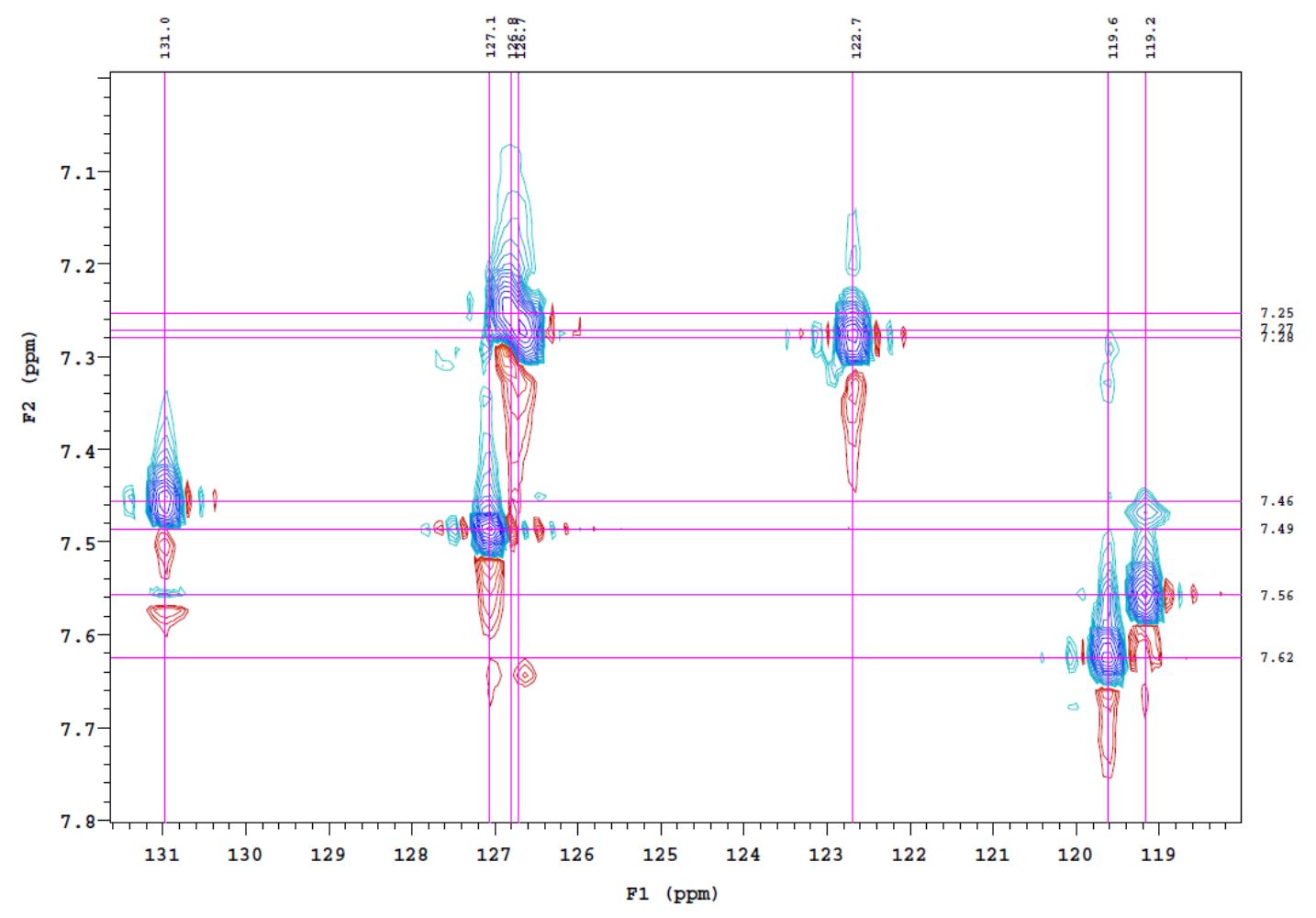

Figure S25. ${ }^{1} \mathrm{H}^{13}{ }^{13} \mathrm{gHSQC}$ spectrum of Et-Au-FO $\left(500 \mathrm{MHz} / 125 \mathrm{MHz}, \mathrm{CDCl}_{3}\right.$ ), (expanded region F1 118-132).

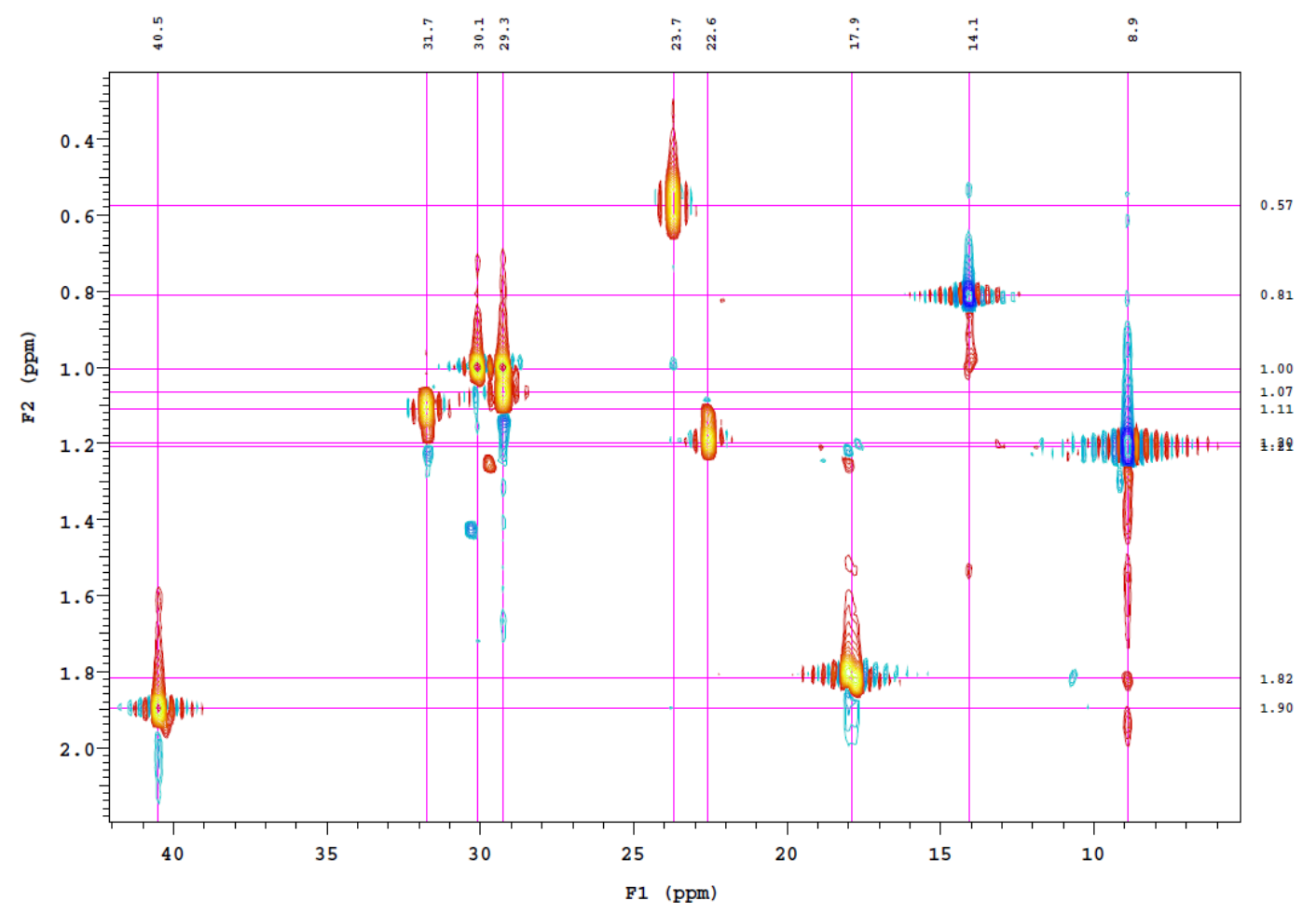

Figure S26. ${ }^{1} \mathrm{H}^{13}{ }^{13} \mathrm{gHSQC}$ spectrum of Et-Au-FO $\left(500 \mathrm{MHz} / 125 \mathrm{MHz}, \mathrm{CDCl}_{3}\right.$ ), (expanded region F1 8-42). 


\section{NMR Spectra of Ph-Au-FO}

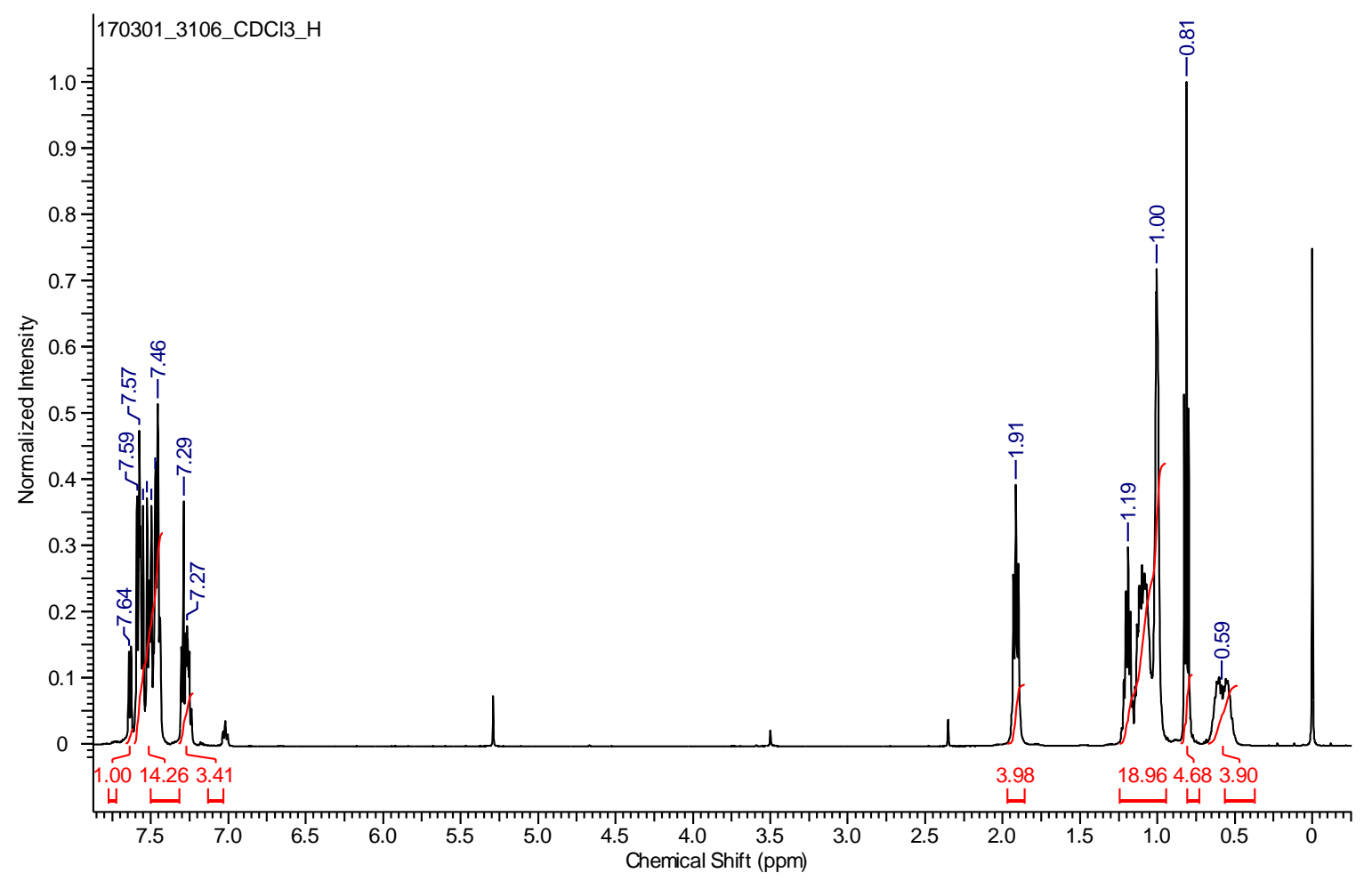

Figure S27. ${ }^{1} \mathrm{H}$ NMR spectrum of Ph-Au-FO (500 MHz, $\left.\mathrm{CDCl}_{3}\right)$.

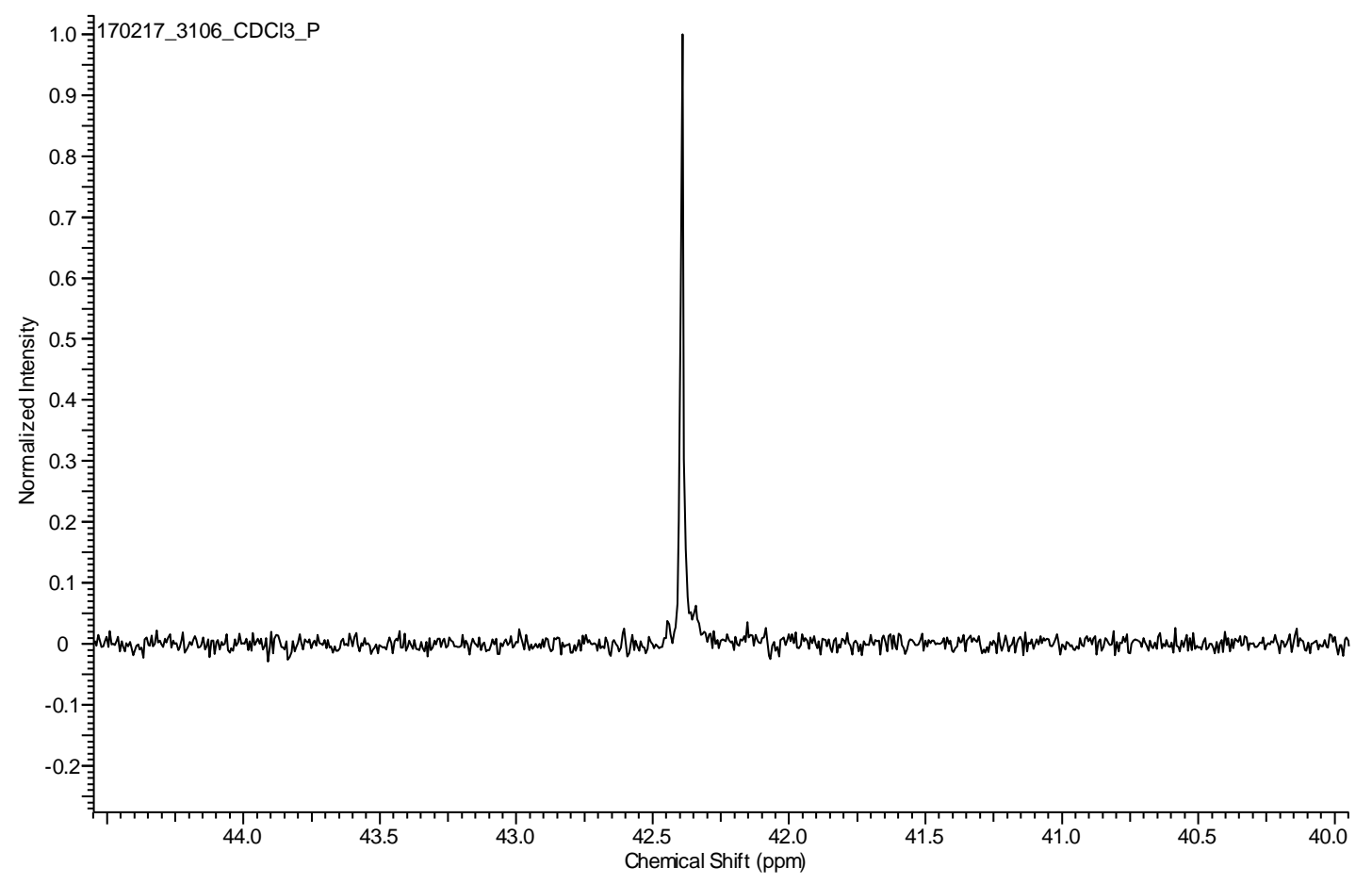

Figure S28. ${ }^{31} \mathrm{P}$ NMR spectrum of Ph-Au-FO (121 MHz, $\left.\mathrm{CDCl}_{3}\right)$. 


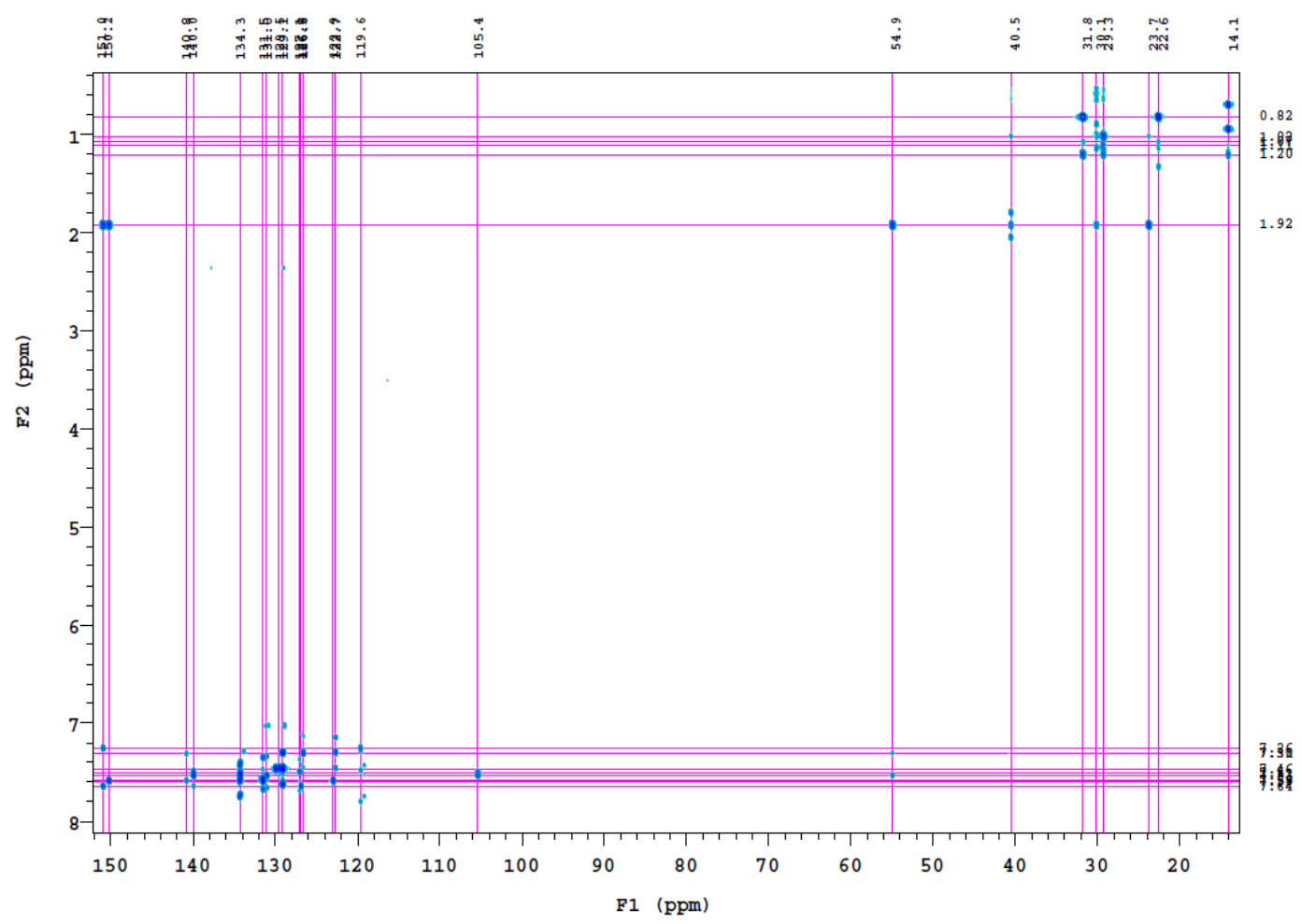

Figure S29. ${ }^{1} \mathrm{H}-{ }^{13} \mathrm{C}$ gHMBC spectrum of Ph-Au-FO $\left(500 \mathrm{MHz} / 125 \mathrm{MHz}, \mathrm{CDCl}_{3}\right)$.

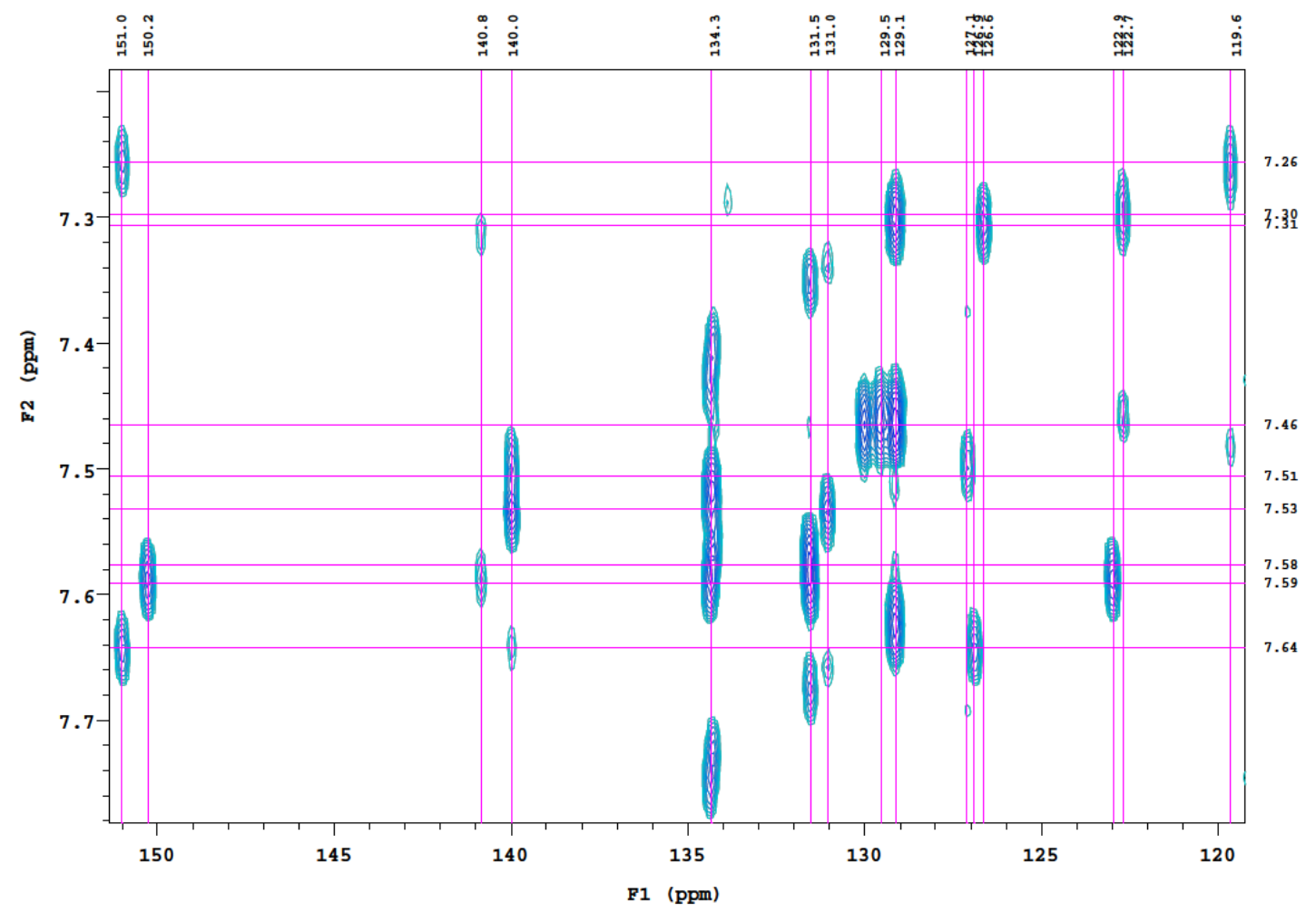

Figure S30. ${ }^{1} \mathrm{H}_{-}{ }^{13} \mathrm{C}$ gHMBC spectrum of Ph-Au-FO $\left(500 \mathrm{MHz} / 125 \mathrm{MHz}, \mathrm{CDCl}_{3}\right.$ ), (expanded region $\mathrm{F} 1$ 119-152). 


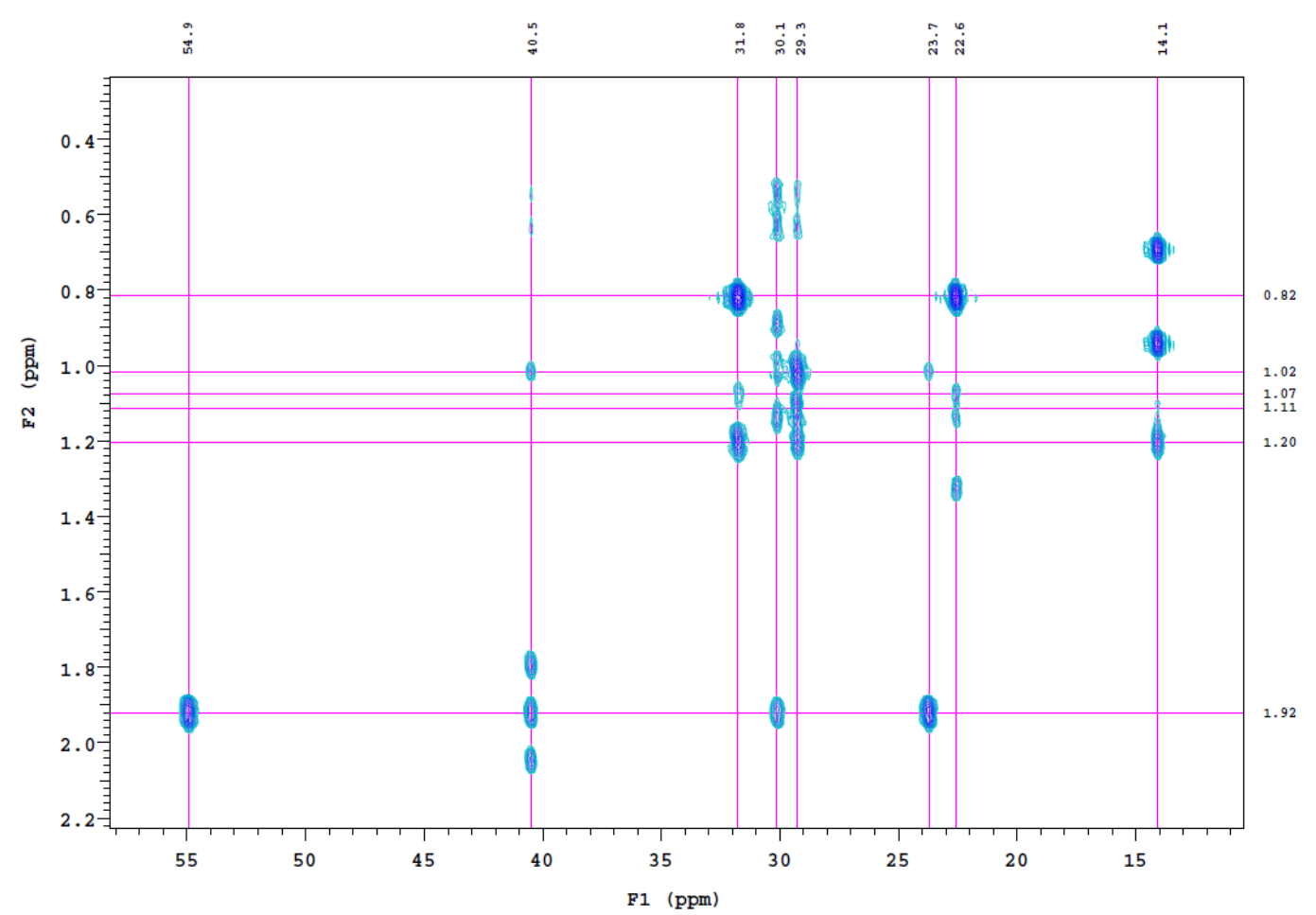

Figure S31. ${ }^{1} \mathrm{H}_{-}{ }^{13} \mathrm{C}$ gHMBC spectrum of Ph-Au-FO $\left(500 \mathrm{MHz} / 125 \mathrm{MHz}, \mathrm{CDCl}_{3}\right.$ ), (expanded region $\mathrm{F} 1$ 13-55).

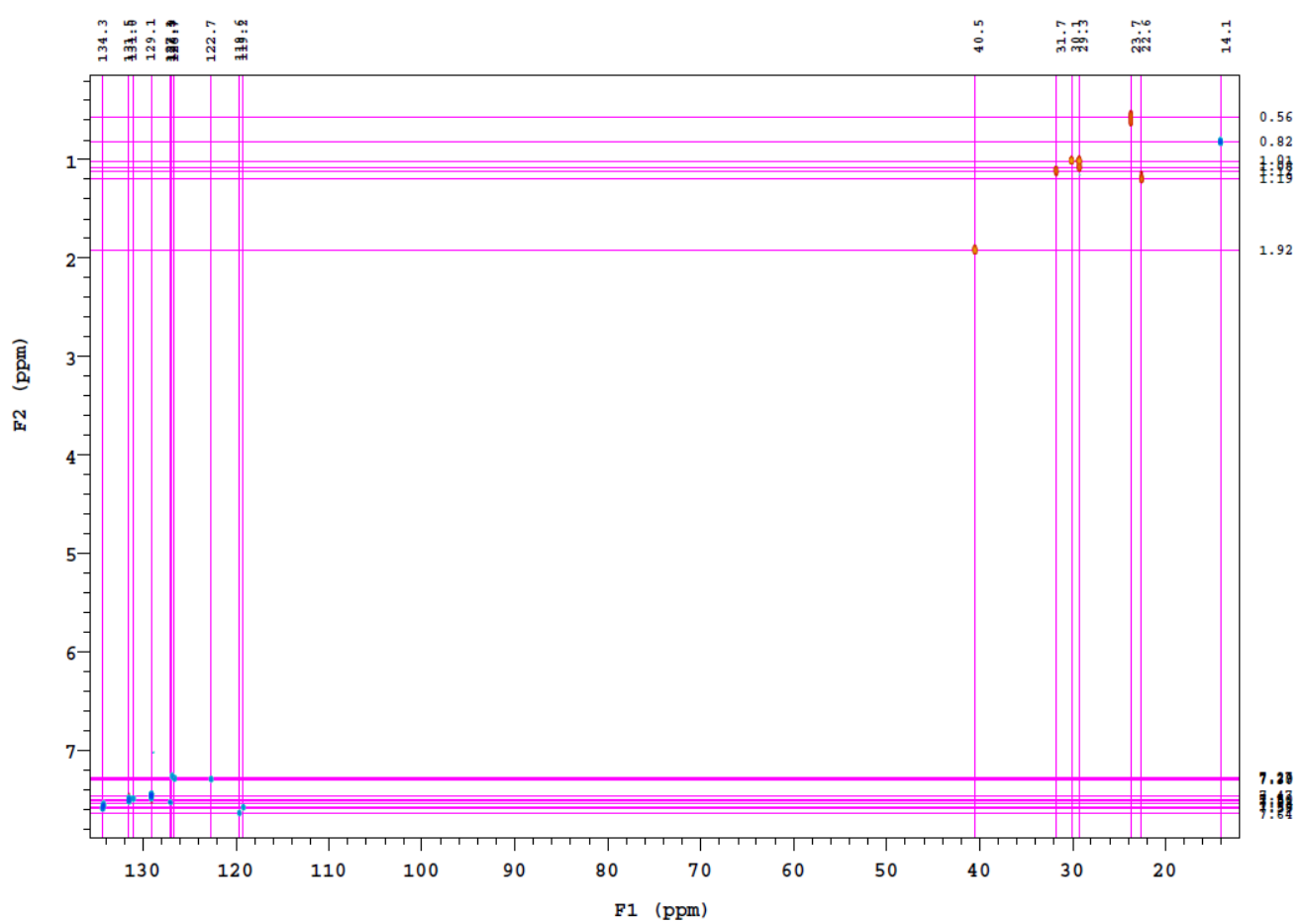

Figure S32. ${ }^{1} \mathrm{H}-{ }^{13} \mathrm{C}$ gHSQC spectrum of Ph-Au-FO $\left(500 \mathrm{MHz} / 125 \mathrm{MHz}, \mathrm{CDCl}_{3}\right)$. 


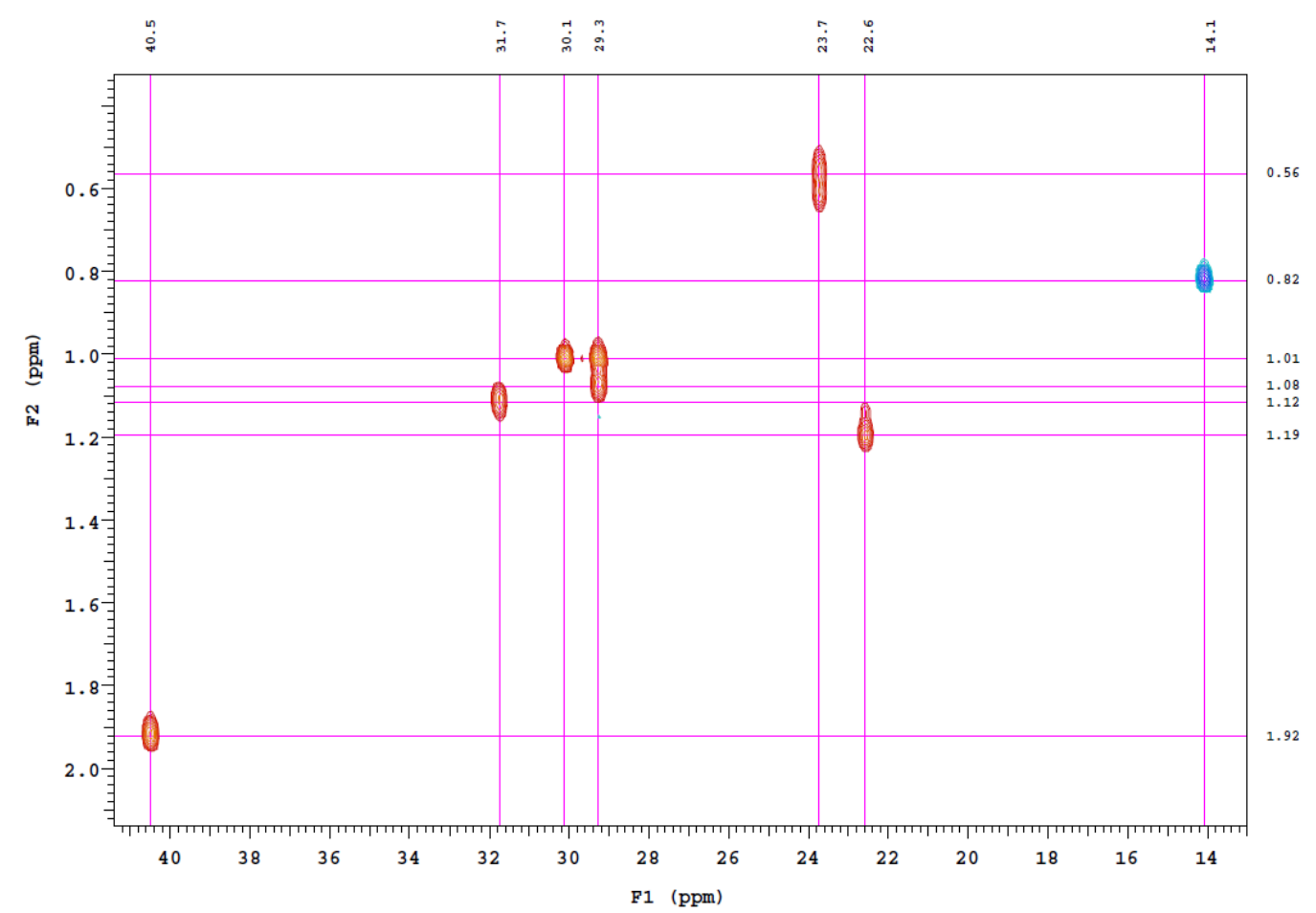

Figure S33. ${ }^{1} \mathrm{H}_{-}{ }^{13} \mathrm{C}$ gHSQC spectrum of Ph-Au-FO $\left(500 \mathrm{MHz} / 125 \mathrm{MHz}, \mathrm{CDCl}_{3}\right)$, (expanded region $\mathrm{F} 1$ 13-50).

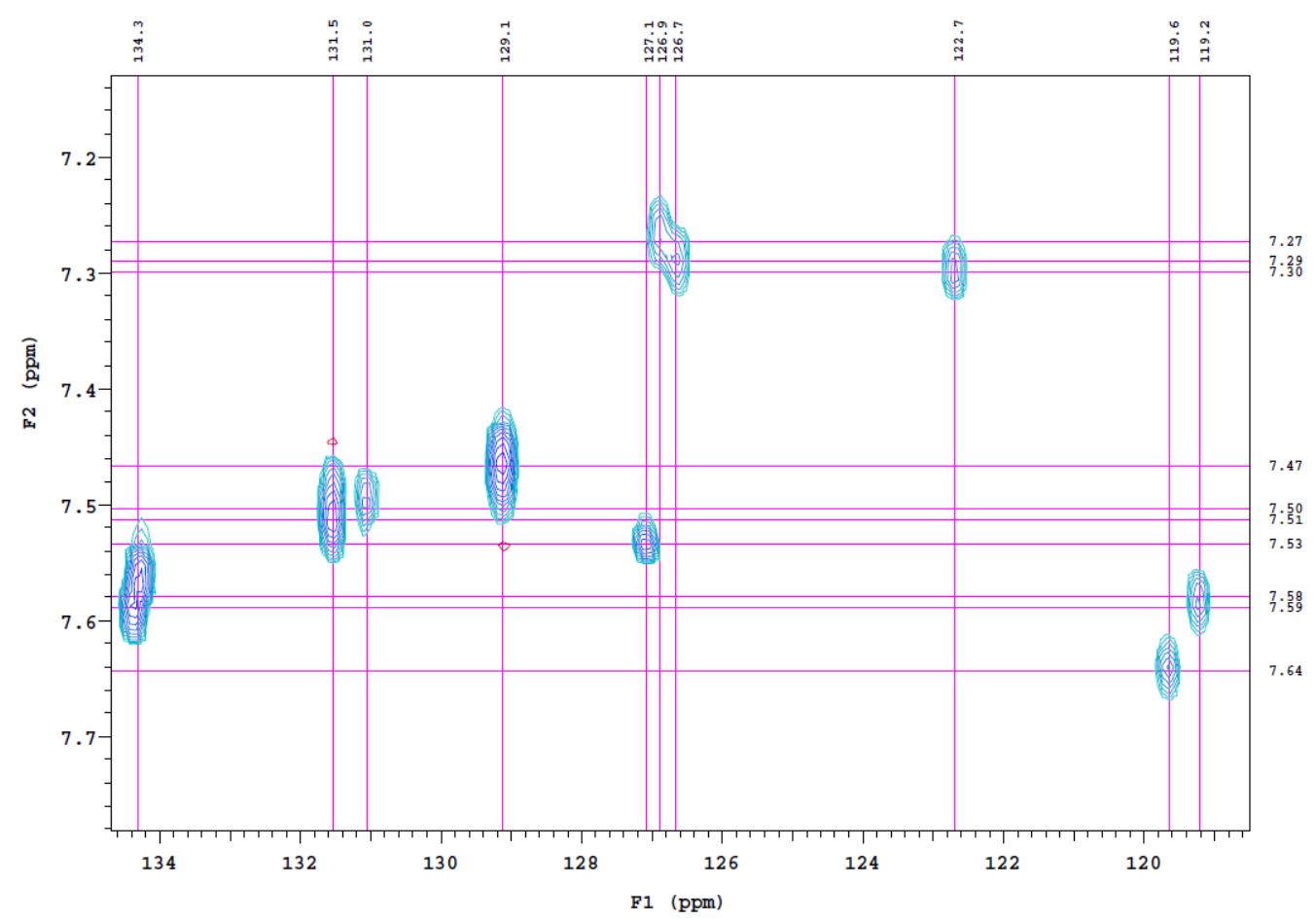

Figure S34. ${ }^{1} \mathrm{H}_{-}{ }^{13} \mathrm{C}$ gHSQC spectrum of Ph-Au-FO $\left(500 \mathrm{MHz} / 125 \mathrm{MHz}, \mathrm{CDCl}_{3}\right.$ ), (expanded region $F 1$ 115-135). 


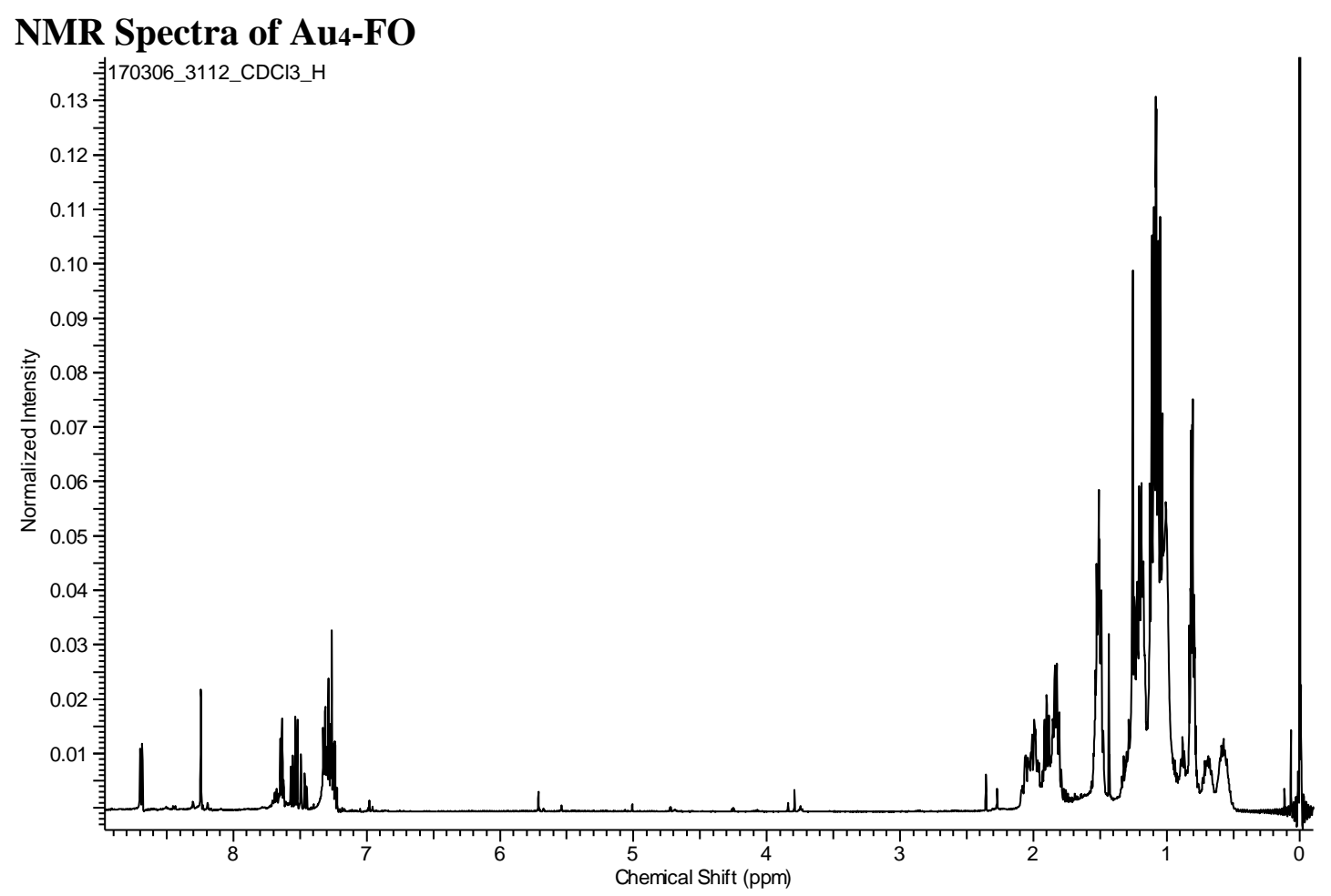

Figure S35. ${ }^{1} \mathrm{H}$ NMR spectrum of $\mathbf{A u} 4-\mathbf{F O}\left(500 \mathrm{MHz}, \mathrm{CDCl}_{3}\right)$.

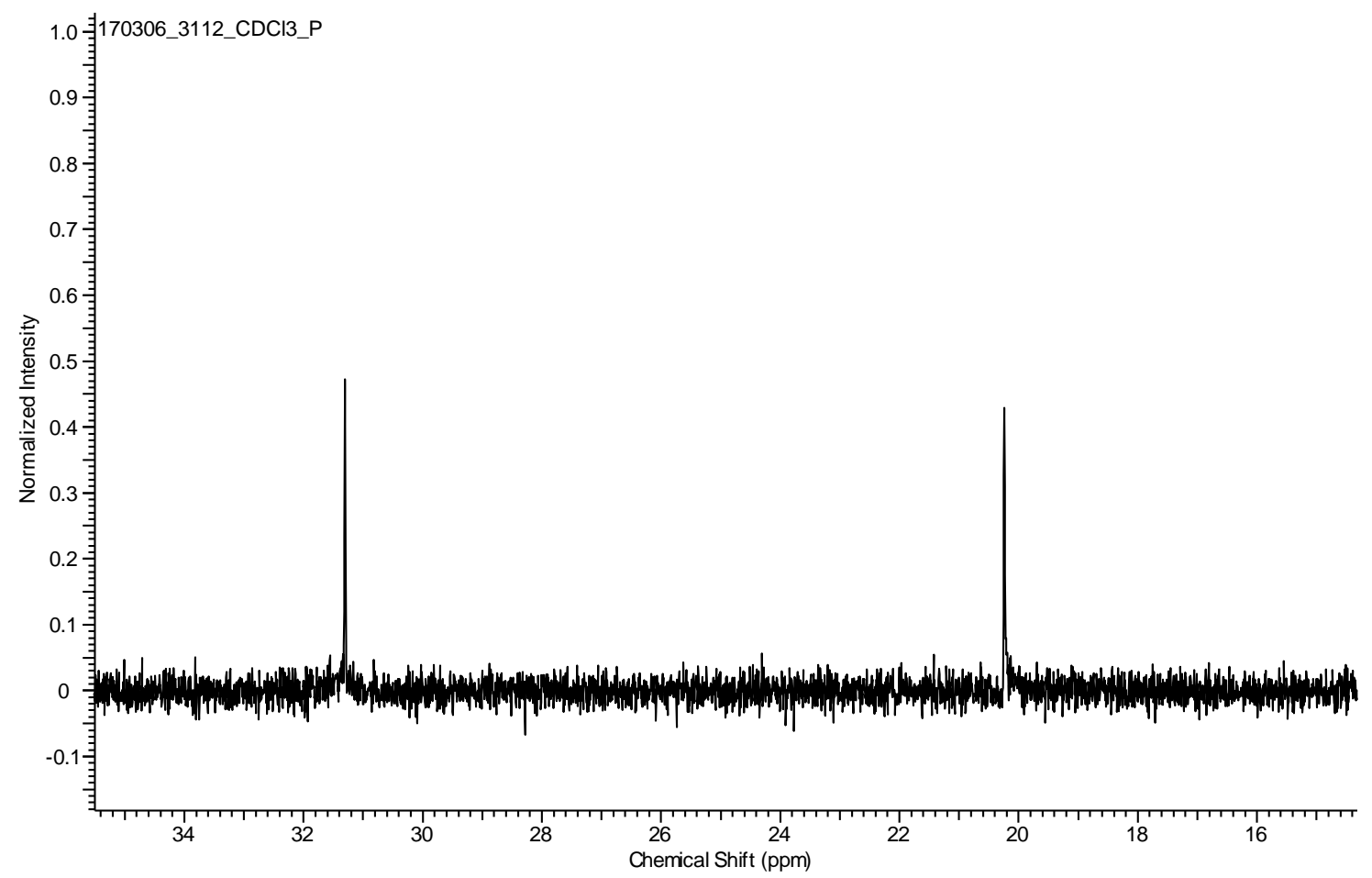

Figure S36. ${ }^{31} \mathrm{P}$ NMR spectrum of Au4-FO $\left(121 \mathrm{MHz}, \mathrm{CDCl}_{3}\right)$. 


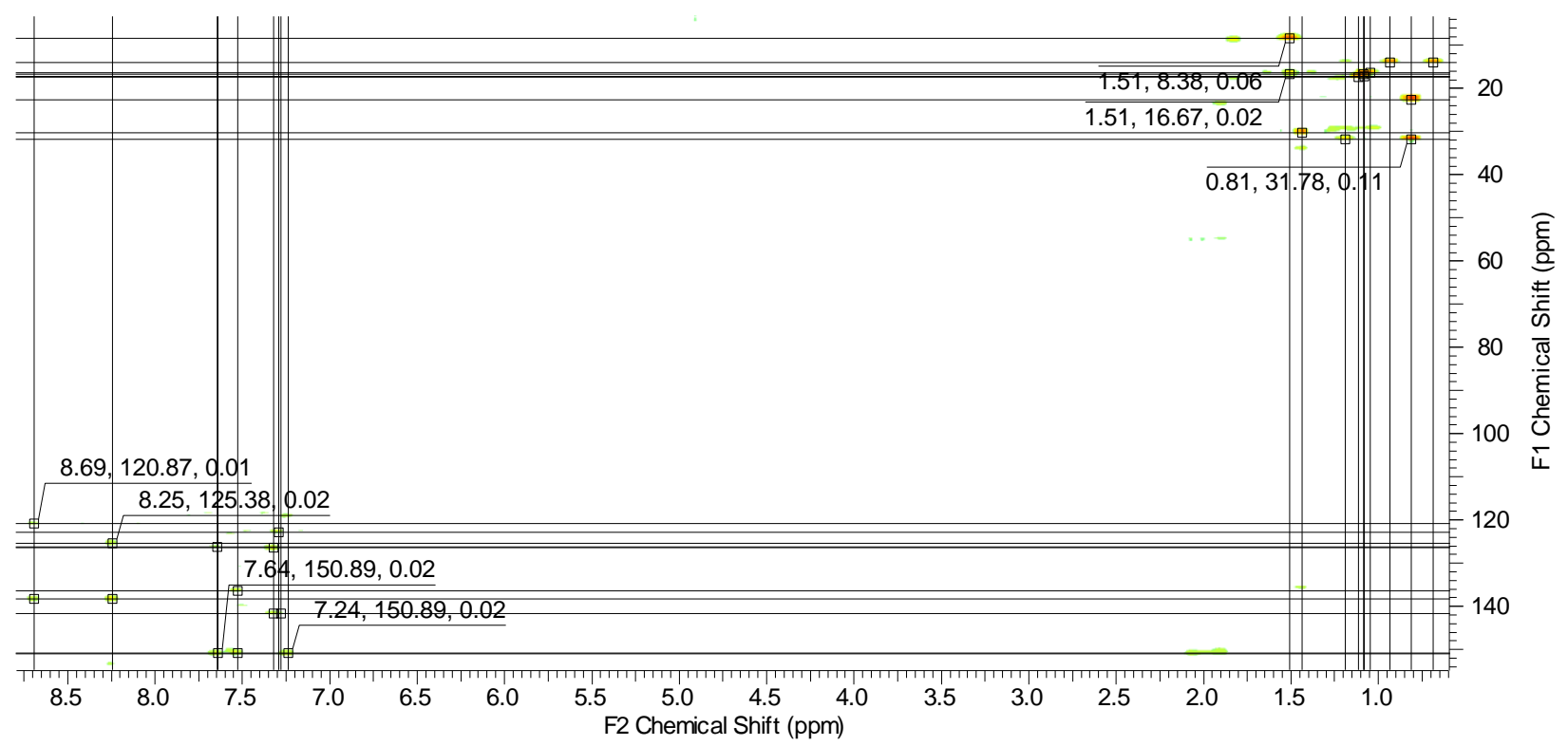

Figure S37. ${ }^{1} \mathrm{H}-{ }^{13} \mathrm{C}$ gHMBC spectrum of Au4-FO $\left(500 \mathrm{MHz} / 125 \mathrm{MHz}, \mathrm{CDCl}_{3}\right)$.

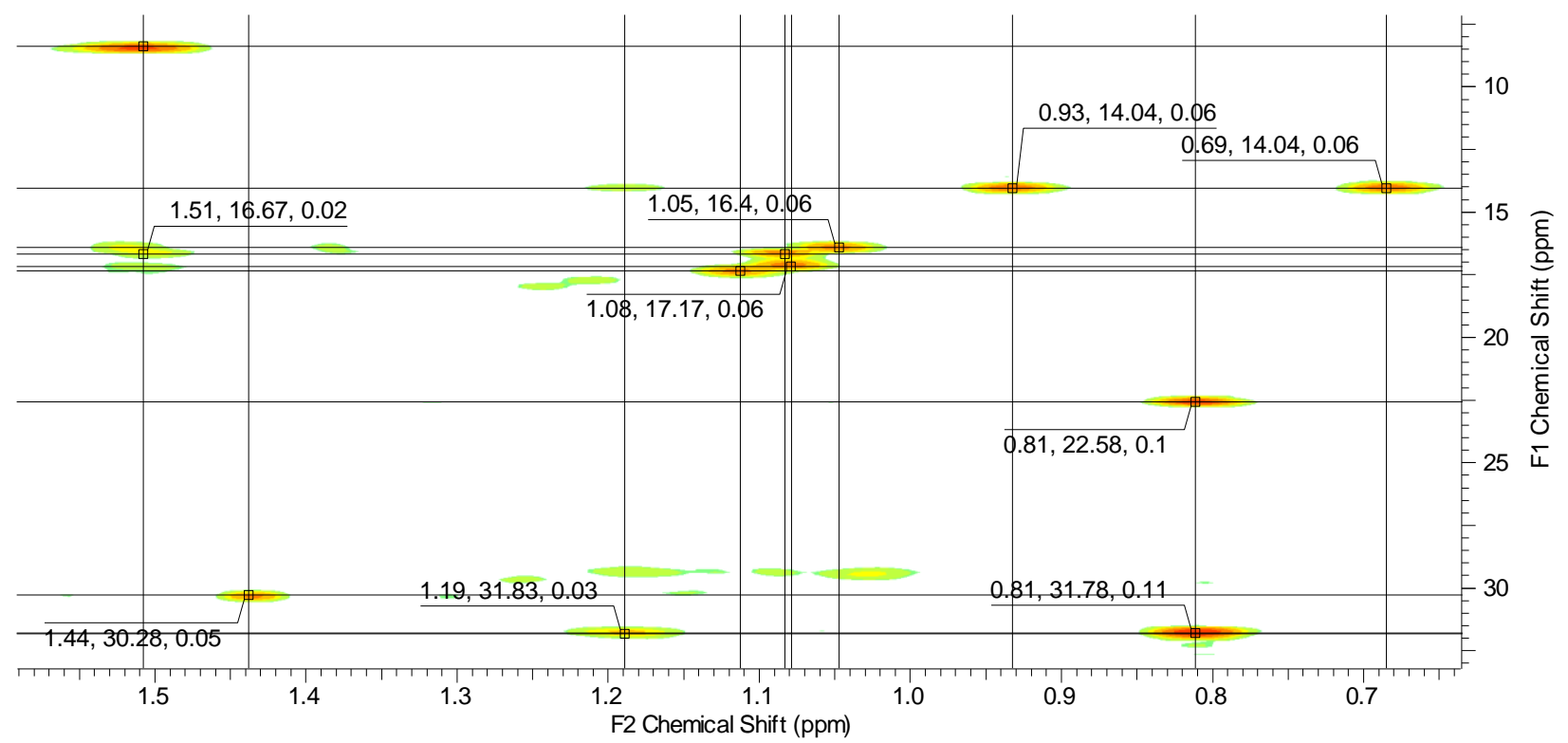

Figure S38. ${ }^{1} \mathrm{H}_{-}{ }^{13} \mathrm{C}$ gHMBC spectrum of Au4-FO $\left(500 \mathrm{MHz} / 125 \mathrm{MHz}, \mathrm{CDCl}_{3}\right.$ ), (expanded region F1 9.5-35). 


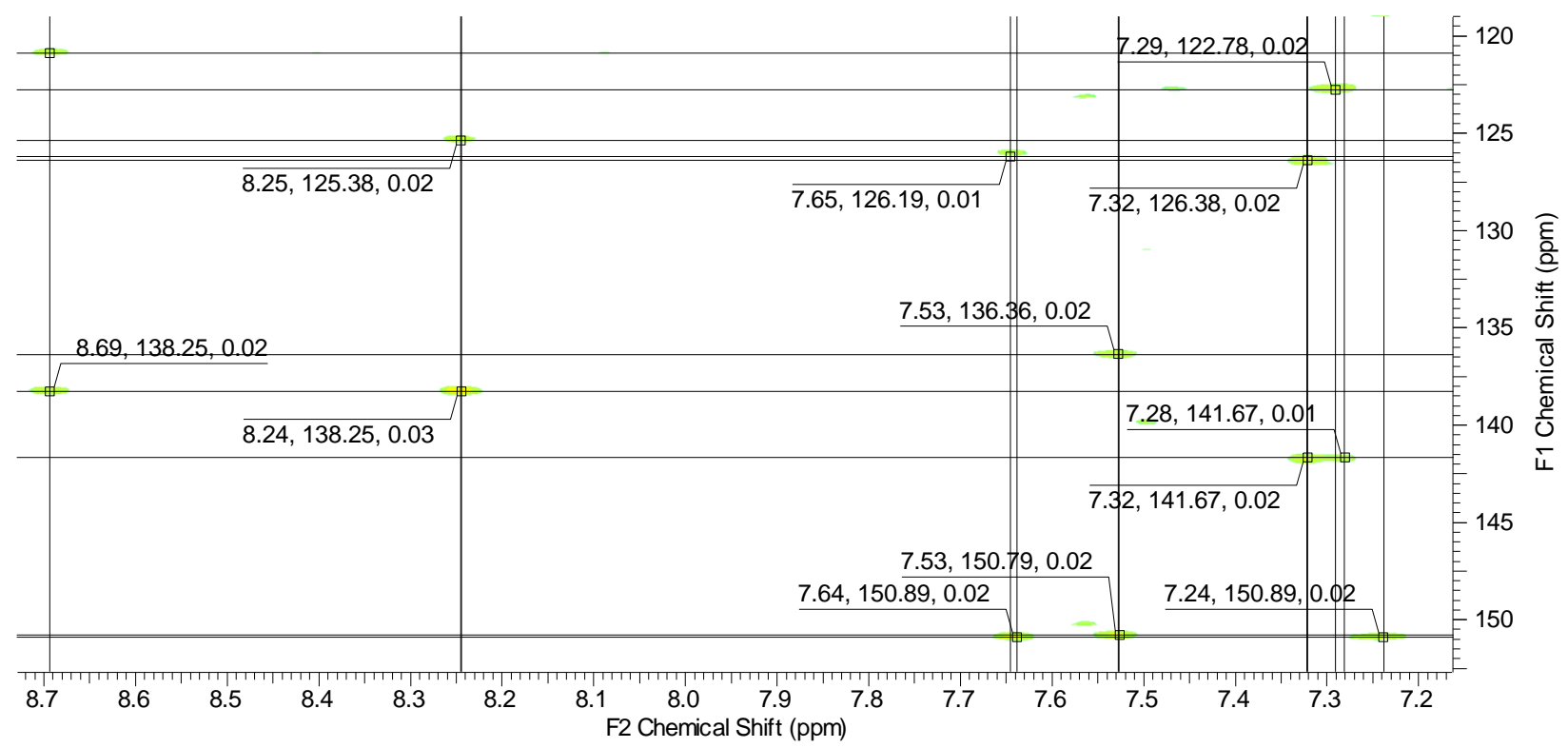

Figure S39. ${ }^{1} \mathrm{H}_{-}{ }^{13} \mathrm{C}$ gHMBC spectrum of Au4-FO (500 MHz / $125 \mathrm{MHz}, \mathrm{CDCl}_{3}$ ), (expanded region $\mathrm{F} 1$ 120-151).

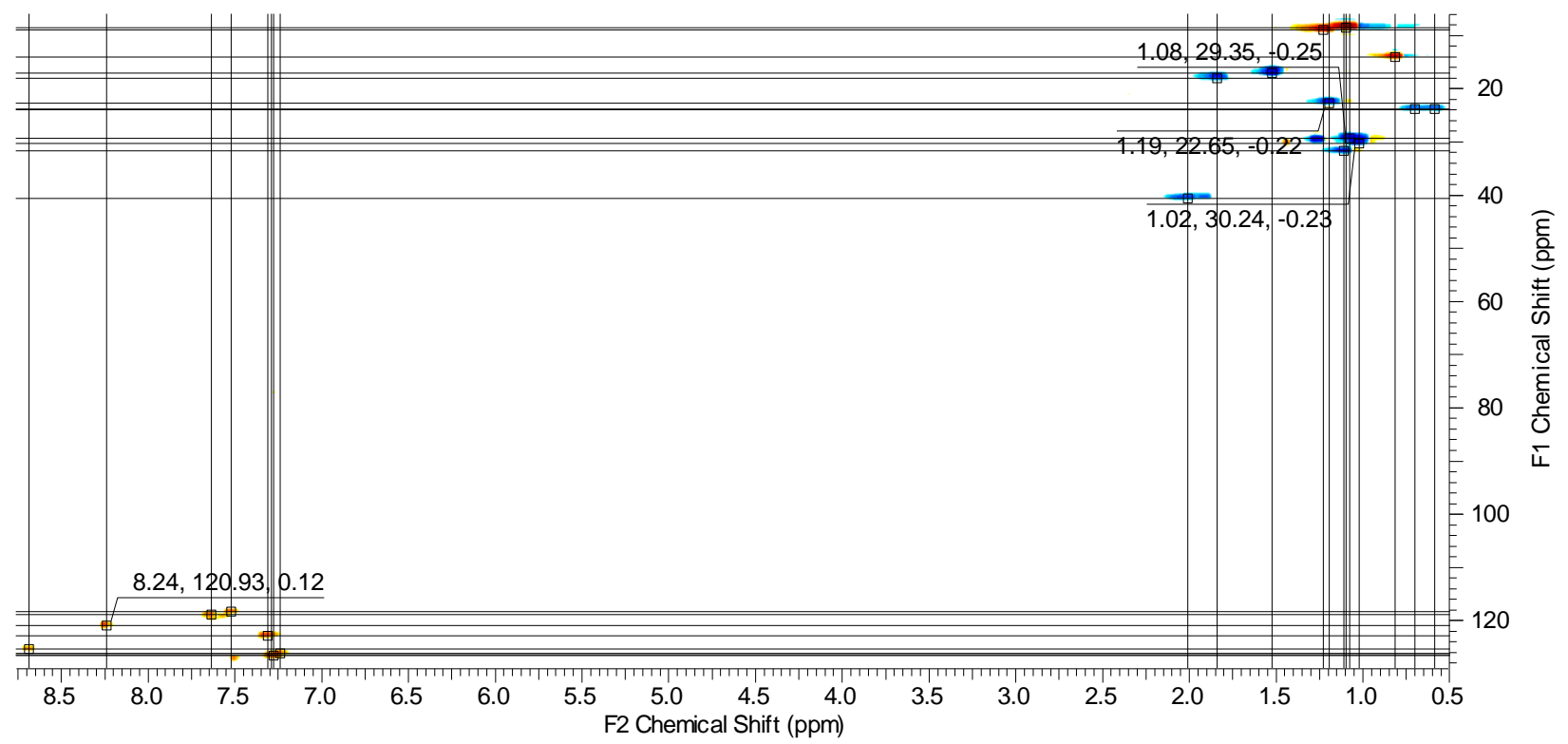

Figure S40. ${ }^{1} \mathrm{H}_{-}{ }^{13} \mathrm{C}$ gHSQC spectrum of Au4-FO $\left(500 \mathrm{MHz} / 125 \mathrm{MHz}, \mathrm{CDCl}_{3}\right)$. 


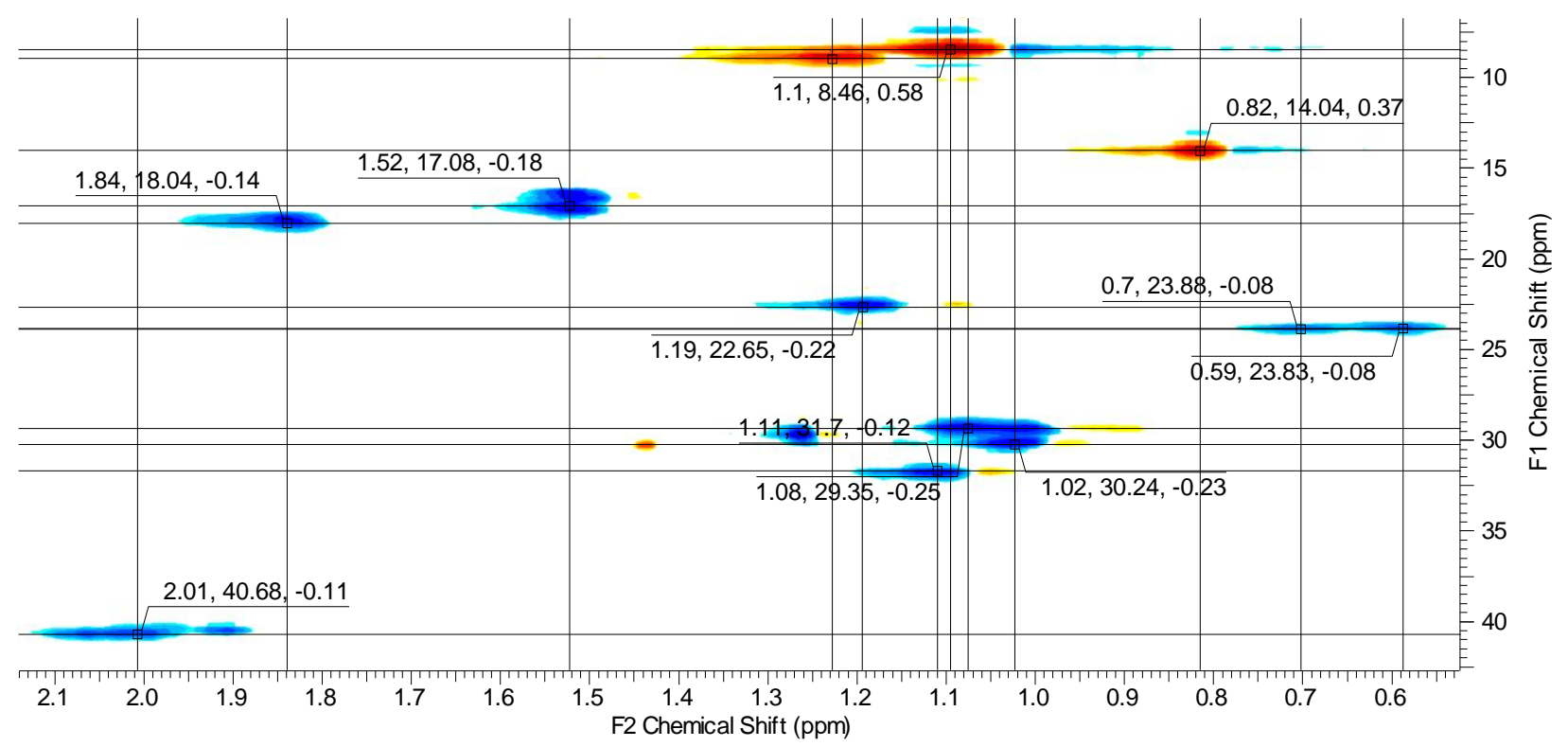

Figure S41. ${ }^{1} \mathrm{H}_{-}{ }^{13} \mathrm{C}$ gHSQC spectrum of Au4-FO $\left(500 \mathrm{MHz} / 125 \mathrm{MHz}, \mathrm{CDCl}_{3}\right.$ ), (expanded region F1 9-42).

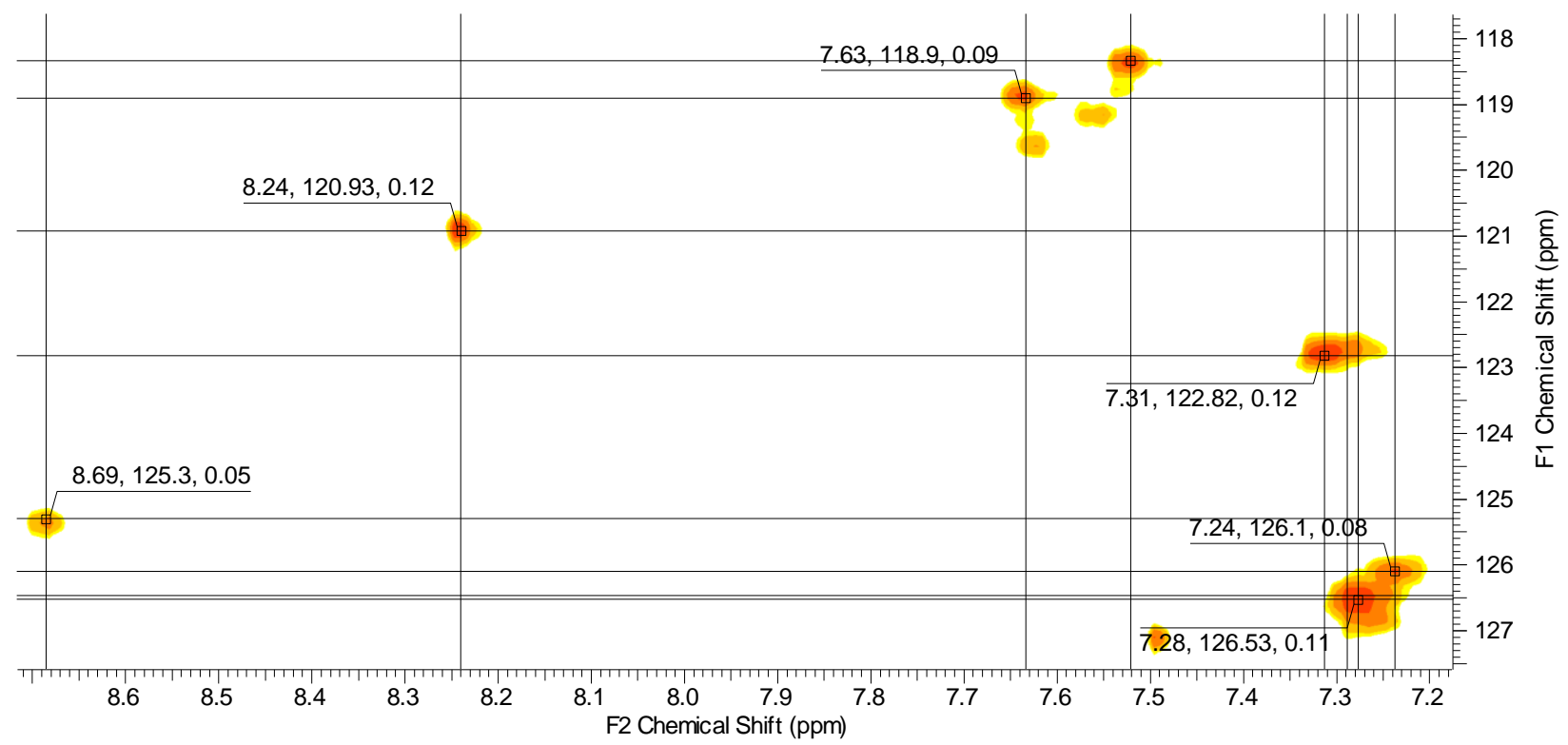

Figure S42. ${ }^{1} \mathrm{H}_{-}{ }^{13} \mathrm{C}$ gHSQC spectrum of Au4-FO (500 MHz / $125 \mathrm{MHz}, \mathrm{CDCl}_{3}$ ), (expanded region $\mathrm{F} 1$ 118-128). 


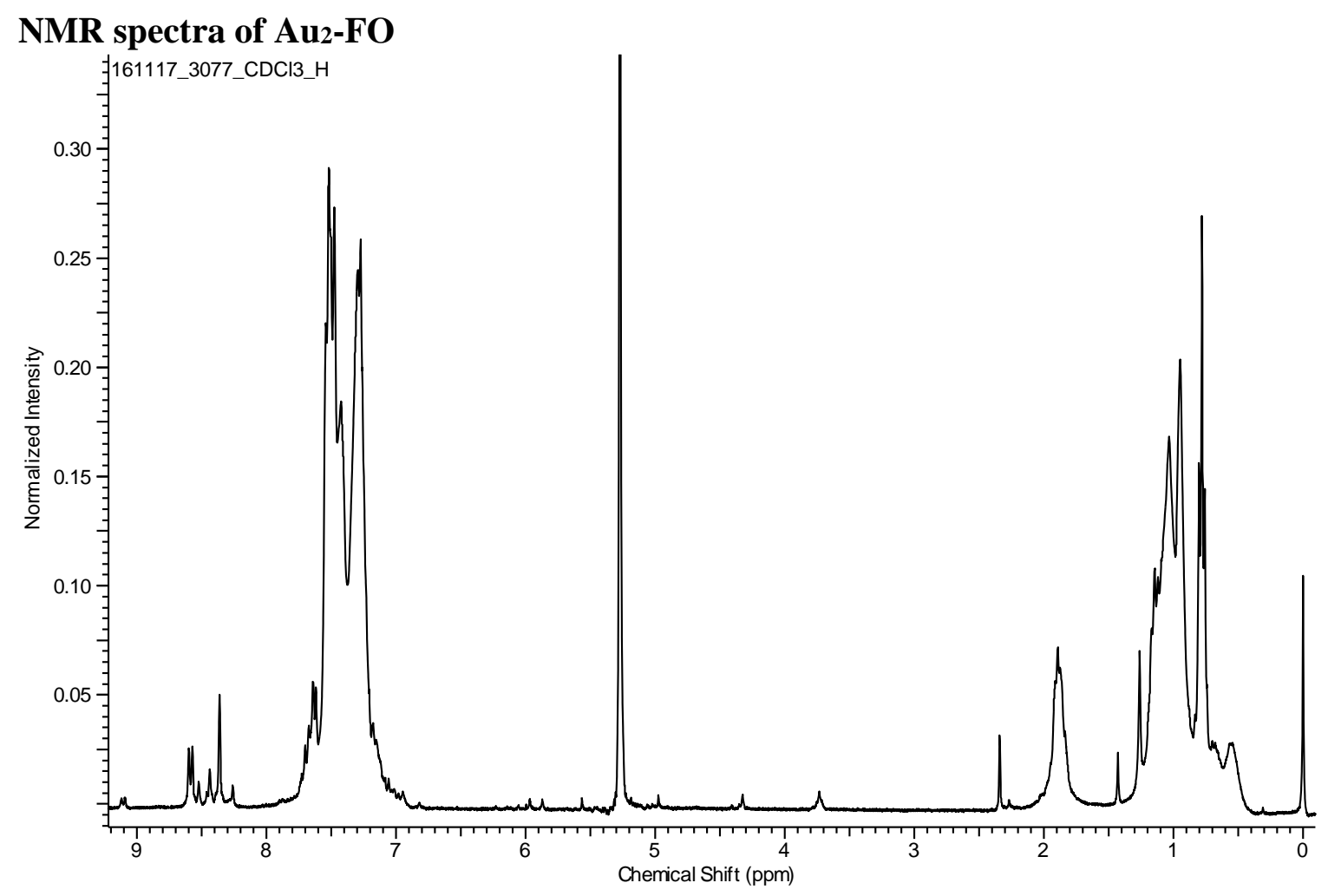

Figure S43. ${ }^{1} \mathrm{H}$ NMR spectrum of $\mathbf{A u}_{2}-\mathbf{F O}\left(500 \mathrm{MHz}, \mathrm{CDCl}_{3}\right)$.

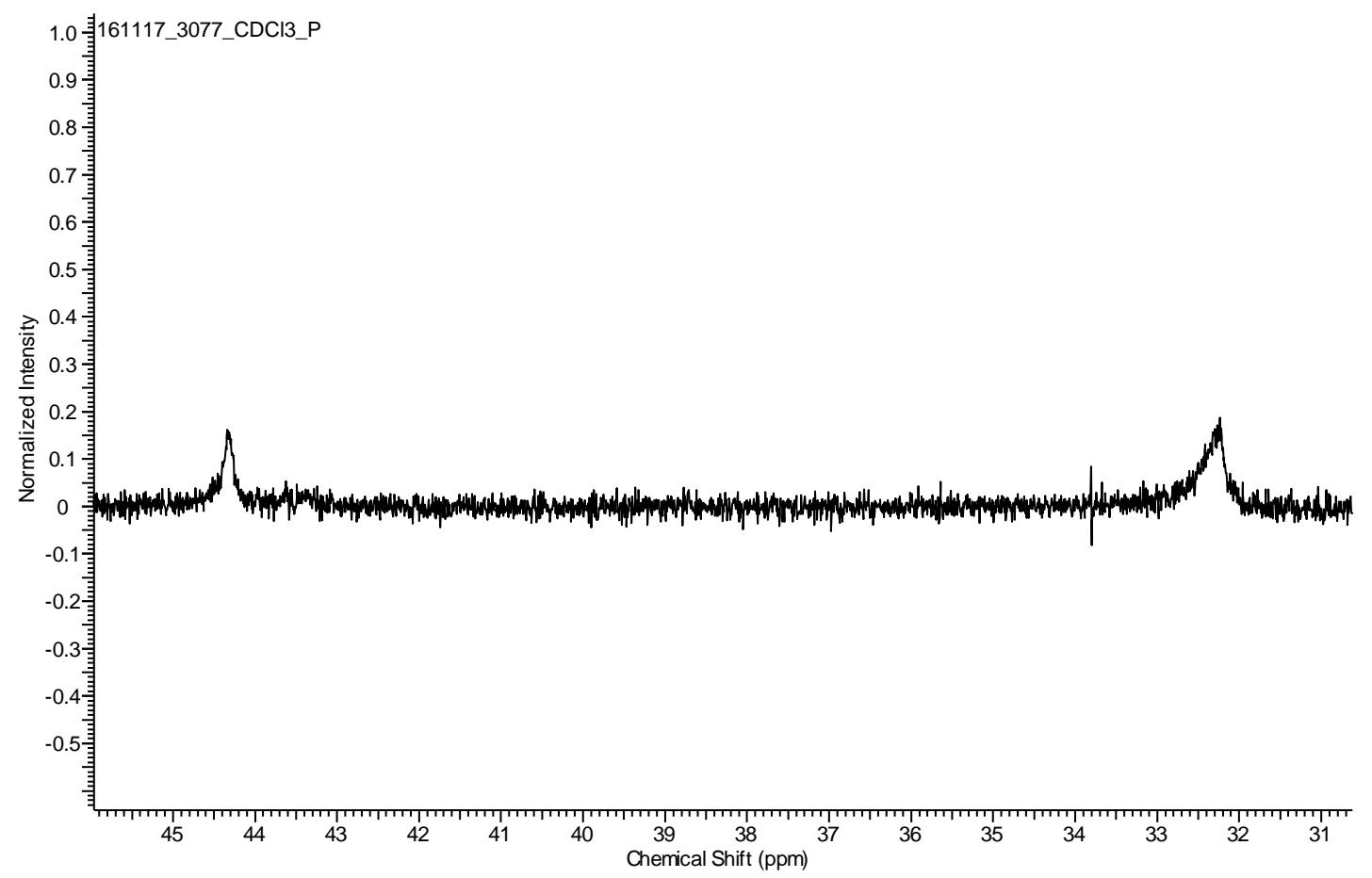

Figure S44. ${ }^{31} \mathrm{P}$ NMR spectrum of Au2-FO (121 MHz, $\left.\mathrm{CDCl}_{3}\right)$. 


\section{References}

1. Graham, K. R., Morphology control in polymer light emitting diodes and molecular bulkheterojunction photovoltaics. University of Florida,: Gainesville, Fla., 2011. http://purl.fcla.edu/fcla/etd/UFE0043336.

2. Forrest, S. R.; Bradley, D. D. C.; Thompson, M. E., Measuring the efficiency of organic lightemitting devices. Adv. Mater. 2003, 15, 1043-1048. 10.1002/adma.200302151

3. M. J. Frisch, G. W. T., H. B. Schlegel, G. E. Scuseria, M. A. Robb, J. R. Cheeseman, G. Scalmani, V. Barone, B. Mennucci, G. A. Petersson, H. Nakatsuji, M. Caricato, X. Li, H. P. Hratchian, A. F. Izmaylov, J. Bloino, G. Zheng, J. L. Sonnenberg, M. Hada, M. Ehara, K. Toyota, R. Fukuda, J. Hasegawa, M. Ishida, T. Nakajima, Y. Honda, O. Kitao, H. Nakai, T. Vreven, J. A. Montgomery, Jr., J. E. Peralta, F. Ogliaro, M. Bearpark, J. J. Heyd, E. Brothers, K. N. Kudin, V. N. Staroverov, T. Keith, R. Kobayashi, J. Normand, K. Raghavachari, A. Rendell, J. C. Burant, S. S. Iyengar, J. Tomasi, M. Cossi, N. Rega, J. M. Millam, M. Klene, J. E. Knox, J. B. Cross, V. Bakken, C. Adamo, J. Jaramillo, R. Gomperts, R. E. Stratmann, O. Yazyev, A. J. Austin, R. Cammi, C. Pomelli, J. W. Ochterski, R. L. Martin, K. Morokuma, V. G. Zakrzewski, G. A. Voth, P. Salvador, J. J. Dannenberg, S. Dapprich, A. D. Daniels, O. Farkas, J. B. Foresman, J. V. Ortiz, J. Cioslowski, and D. J. Fox Gaussian 09, Revision D.01; Gaussian, Inc.: Wallingford, CT., 2013.

4. Becke, A. D., Density-functional exchange-energy approximation with correct asymptotic behavior. Phys. Rev. A 1988, 38 (6), 3098-3100.

5. Lee, C.; Yang, W.; Parr, R. G., Development of the Colle-Salvetti correlation-energy formula into a functional of the electron density. Phys. Rev. B 1988, 37 (2), 785-789.

6. Becke, A. D., Density-functional thermochemistry. III. The role of exact exchange. J. Chem. Phys. 1993, 98 (7), 5648-5652.

7. Ditchfield, R.; Hehre, W. J.; Pople, J. A., Self-Consistent Molecular-Orbital Methods. IX. An Extended Gaussian-Type Basis for Molecular-Orbital Studies of Organic Molecules. J. Chem. Phys. 1971, 54 (2), 724-728.

8. Schwerdtfeger, P.; Dolg, M.; Schwarz, W. H. E.; Bowmaker, G. A.; Boyd, P. D. W., Relativistic effects in gold chemistry. I. Diatomic gold compounds. J.Chem.Phys. 1989, 91 (3), 1762-1774.

9. Lu, T.; Chen, F., Multiwfn: A multifunctional wavefunction analyzer. J. Comp. Chem. 2011, 33 (5), 580-592. 